\title{
Occurrence of Chemical Contaminants in Peruvian Produce: A Food-Safety Perspective
}

\author{
Oscar A. Galagarza ${ }^{1, *(\mathbb{D})}$, Alejandra Ramirez-Hernandez ${ }^{1} \mathbb{D}$, Haley F. Oliver ${ }^{1}$, Mariel V. Álvarez Rodríguez ${ }^{2} \mathbb{D}$, \\ María del Carmen Valdez Ortiz ${ }^{3}$, Erika Pachari Vera ${ }^{2} \mathbb{D}$, Yakelin Cereceda ${ }^{4}$, Yemina K. Diaz-Valencia ${ }^{2} \mathbb{D}$ and \\ Amanda J. Deering ${ }^{1}$ (D)
}

1 Department of Food Science, Purdue University, 745 Agriculture Mall Drive, West Lafayette, IN 47907, USA; alejaramirez02@gmail.com (A.R.-H.); hfoliver@purdue.edu (H.F.O.); adeering@purdue.edu (A.J.D.)

2 Academic Department of Process Engineering, Universidad Nacional de San Agustin, Arequipa 04001, Peru; malvarezro@unsa.edu.pe (M.V.Á.R.); epachari@unsa.edu.pe (E.P.V.); ydiazva@unsa.edu.pe (Y.K.D.-V.)

3 Department of Biological Sciences, Universidad Nacional de San Agustin, Arequipa 04001, Peru; mvaldezor@unsa.edu.pe

4 Department of Sociology, Universidad Nacional de San Agustin, Arequipa 04001, Peru; ycereceda@unsa.edu.pe

* Correspondence: ogalagarza@gmail.com; Tel.: +1-404-824-2607

Citation: Galagarza, O.A.;

Ramirez-Hernandez, A.; Oliver, H.F.; Álvarez Rodríguez, M.V.; Valdez Ortiz, M.d.C.; Pachari Vera, E.; Cereceda, Y.; Diaz-Valencia, Y.K.; Deering, A.J. Occurrence of Chemical Contaminants in Peruvian Produce: A Food-Safety Perspective. Foods 2021, 10, 1461. https://doi.org/ 10.3390 / foods 10071461

Academic Editor:

Roberto Romero-González

Received: 5 June 2021

Accepted: 22 June 2021

Published: 24 June 2021

Publisher's Note: MDPI stays neutral with regard to jurisdictional claims in published maps and institutional affiliations.

Copyright: (c) 2021 by the authors. Licensee MDPI, Basel, Switzerland. This article is an open access article distributed under the terms and conditions of the Creative Commons Attribution (CC BY) license (https:/ / creativecommons.org/licenses/by/ $4.0 /)$.
Abstract: The presence of chemical contaminants in agricultural products is a continued food-safety challenge in Peru. This country has robust agriculture potential, but its output of fruits and vegetables is severely impacted by massive mining activities, as well as poor farming practices, including the use of polluted irrigation water, misuse of pesticides, and inadequate postharvest conditions. This review examines the current scientific knowledge on the levels of pesticide residues, heavy metals, and mycotoxins on crops produced in Peru. The available data shows that several crop varieties are contaminated with these classes of chemical contaminants, and at levels that exceed the national and international permissible limits. The abundance of chemical contaminants in produce indicates a relevant food-safety issue, which increases the risks of chronic human diseases, like cancer-a leading cause of death in Peru. Finally, this review presents recommendations to address these contamination problems in produce grown in the Andean country.

Keywords: Peruvian agriculture; food safety; public health; pesticide residues; heavy metals; mycotoxins

\section{Introduction}

Peru is a developing economy with a massive agricultural output, which has contributed to the country's socioeconomic prosperity. Production from the agriculture sector has a net worth of USD 5.5 billion, roughly a 7\% share of Peru's gross domestic product (GDP), and supports $30 \%$ of the country's labor force [1,2]. Vegetables, fruits, and grains are important agricultural crops, as they are key components of the Peruvian diet and produce exports. Trade of agricultural products is vital for the country's economy, remaining only behind mining. Traditional products (e.g., sugar and coffee) represent the dominant crop varieties exported, but the exportation of nontraditional products (e.g., asparagus, mango, avocado, and grapes) has increased dramatically in the past two decades. Agricultural exports contributed USD 3.1 billion in 2019, and the top international markets included the United States, the European Union, China, Chile, Colombia, and Mexico [1]. These increases in production and exports of fruits and vegetables are due to global consumer trends shifting toward health and wellness [3].

Despite the success of agricultural economy in Peru, intensification of agricultural production has come with important challenges. Prominent issues include lack of infrastructure investment, inadequate financial resources, limited agriculture technical knowledge, water scarcity, and poor water quality [4]. Moreover, these challenges can increase the 
likelihood of chemical contaminants in agricultural products, creating one major contemporary food-safety issue. The abundance of these pollutants can be difficult to remediate, given the country's limited access to up-to-date quality data on environmental resources (e.g., irrigation water), and the absence of data attributing domestic foodborne illnesses to chemically contaminated foods.

Foodborne illnesses are an important public-health problem in Peru. Roughly 6098 people fall ill from contaminated foods each year [5]. The occurrence of foodborne diseases is not only vital from the human-welfare standpoint, but also because approximately USD 500 million is lost annually in productivity and healthcare expenses [6]. Additionally, Peru is one of the countries in the Americas that is categorized under the World Health Organization stratum " $\mathrm{D}$ ", which indicates a high child and adult mortality from foodborne disease [7].

Although foodborne outbreaks are more frequently due to contamination with pathogenic microorganisms, chemical compounds are also common contaminants of fresh produce. It is estimated that one to two foodborne outbreaks are attributed to chemical pollutants each year, yet precise numbers of affected individuals are not available [5]. Chemical contaminants are either of natural or anthropogenic origin, and are potentially toxic when the polluted crops are consumed by people. Problematic chemicals that frequently contaminate agricultural crops include heavy metals, mycotoxins, and pesticide residues. The health effects of these chemical contaminants can range from acute, such as organ failure, to chronic effects, such as the increased risk of cancer, and neurological disorders [8-11].

There is no safe dose for chemical contaminants, but there are acceptable doses that have been estimated to not elicit signs of toxicity. These acceptable doses are known as maximum limit, and serve as a general guideline for many contaminants across various crop varieties [12]. Compliance with this guideline ensures the harmonization of food safety and trade. Thus, monitoring systems are often established in different countries to ensure that chemical contaminants are below the maximum limits. The weak enforcement in food-safety monitoring, surveillance, and control of such chemical contaminants in Peru makes consumers potentially more vulnerable [13]. More importantly, children, old adults, and immunocompromised people are at a great risk of foodborne illness [14].

Over the last two decades, the number of studies reporting chemical contaminants in Peruvian agricultural crops has been increasing. This is an indication that food-safety concerns are gaining more attention. To the best of our knowledge, however, there is no comprehensive review on chemical contaminants covering the available data on pesticide residues, heavy metals, and mycotoxins in crop varieties cultivated in Peru. This review is a landscape analysis of scientific articles, academic theses, and Peruvian governmental agency reports for the years 2000-2021 that present data on heavy metals, mycotoxins, and pesticide residues, to depict the current safety status of produce grown in Peru. The information presented in this review will enable growers, stakeholders, policymakers, and consumers to have a more comprehensive understanding of current food-safety issues of produce grown in Peru, and advocate for the appropriate changes to current practices.

\section{Peru Food Laws and Regulations for Chemical Contaminants}

Peru has a well-established food-safety system, which is led by the General Directorate of Environmental Health and Food Safety (Dirección General de Salud Ambiental, DIGESA) and the National Service of Agrarian Health (Servicio Nacional de Salud Agraria, SENASA) agencies; the former agency is in charge of monitoring processed foods and beverages, while the latter surveils animal and plant health. Thus, the role of DIGESA is similar to that of the US Food Drug and Administration (FDA), and SENASA is the equivalent of the US Department of Agriculture's Animal and Plant Health Inspection Service (USDA-APHIS) and Food Safety Inspection Service (USDA-FSIS).

Food-safety laws in Peru were established under the legislative decree $\mathrm{N}^{\circ} 1062$. Decree $\mathrm{N}^{\circ}$ 004-2011-AG provides the food-safety guidelines of agrarian products for domestic and international consumption [15]. Some of these reference guidelines are presented 
in Table 1. These Peruvian food safety laws follow the Codex Alimentarius standards as their guidelines to promote food safety [16]. The Codex Alimentarius consists of a collection of standards and practices to ensure that foods are safe for both consumption and international trade; it was established by the Food and Agriculture Organization of the United Nations and the World Health Organization [12].

Table 1. Heavy-metal quality standards for agricultural water and produce in Peru. Data adapted from the Food and Agicultural Organization and the World Health Organization (FAO/WHO), and the Ministry of the Environment [12,17].

\begin{tabular}{|c|c|c|c|c|c|}
\hline \multirow{3}{*}{ Heavy Metal } & \multicolumn{5}{|c|}{ Maximum Contaminant Limits } \\
\hline & \multicolumn{2}{|c|}{ Irrigation Water (mg/L) } & \multirow{2}{*}{ Fruits (mg/kg) } & \multirow{2}{*}{ Vegetables (mg/kg) } & \multirow{2}{*}{ Grains (mg/kg) } \\
\hline & WHO Standards & Peru Standards & & & \\
\hline As & 0.1 & 0.1 & $\mathrm{NE}$ & 0.1 & 0.2 \\
\hline $\mathrm{Cd}$ & 0.01 & 0.01 & 0.2 & $\begin{array}{c}0.1 \text {, except for } \\
0.2 \text { in leafy greens }\end{array}$ & $\begin{array}{l}0.1 \text { in cereals } \\
0.2 \text { in rice } \\
\text { and wheat }\end{array}$ \\
\hline $\mathrm{Pb}$ & 5 & 0.05 & 0.1 & $\begin{array}{l}0.1 \text {, except for } 0.3 \text { in leafy } \\
\text { greens, and } 0.2 \text { in pulses }\end{array}$ & 0.2 \\
\hline $\mathrm{Cr}$ & 0.1 & 0.1 & & $\mathrm{NE}^{*}$ & \\
\hline $\mathrm{Mn}$ & 0.2 & 0.2 & & $5 *$ & \\
\hline $\mathrm{Zn}$ & 2 & 2 & & $100 *$ & \\
\hline $\mathrm{Cu}$ & 0.2 & 0.2 & & $30 *$ & \\
\hline $\mathrm{Hg}$ & NE & 0.001 & & $0.02 *$ & \\
\hline
\end{tabular}

NE, not established. * Value designated for fruits, vegetables, and crops.

Other relevant regulations that are linked to produce food-safety laws include legislation that underlines national standards for quality of irrigation water. Such standards were established under the supreme decree $\mathrm{N}^{\circ} 015-2015-\mathrm{MINAM}$ by the Ministry of the Environment (Ministerio del Ambiente, MINAM) in collaboration with the National Authority of Water (Autoridad Nacional del Agua, ANA), which follows recommendations by the US Environmental Protection Agency (EPA) and the WHO [17,18]. Some of the standards established for heavy metals in irrigation water are included in Table 1.

Compliance with international trade laws is crucial for Peruvian producers who desire to export their crop output. Given that the US and countries in the European Union (EU) are major importers of Peruvian foods, the latter have to meet the respective food-safety requirements. The Food Safety Modernization Act (FSMA), the major food-safety standards in the US, plays a key role in import acceptance in the ports of entry. One FSMA rule in the Foreign Supplier Verification Program requires importers to provide a phytosanitary certificate, issued by Peru's SENASA, that verifies that the product meets all the US foodsafety standards $[19,20]$. A similar rigorous process occurs when exporting to the EU, as the legislation requires that the exporter be certified by SENASA [21]. The ability to comply with export regulations has made the food sector more vibrant, and there has been an improvement in agricultural education and infrastructure primarily [22]. However, this is an ongoing effort to lower the discrepancies in access to these benefits across all the geographical regions of Peru (refer to Figure 1 for a map of Peru); from the Costa (coast) with more mechanized agriculture, to the more small-scale agriculture that predominates in both the Selva (Amazon rainforest) and the Sierra (highlands) [23]. 


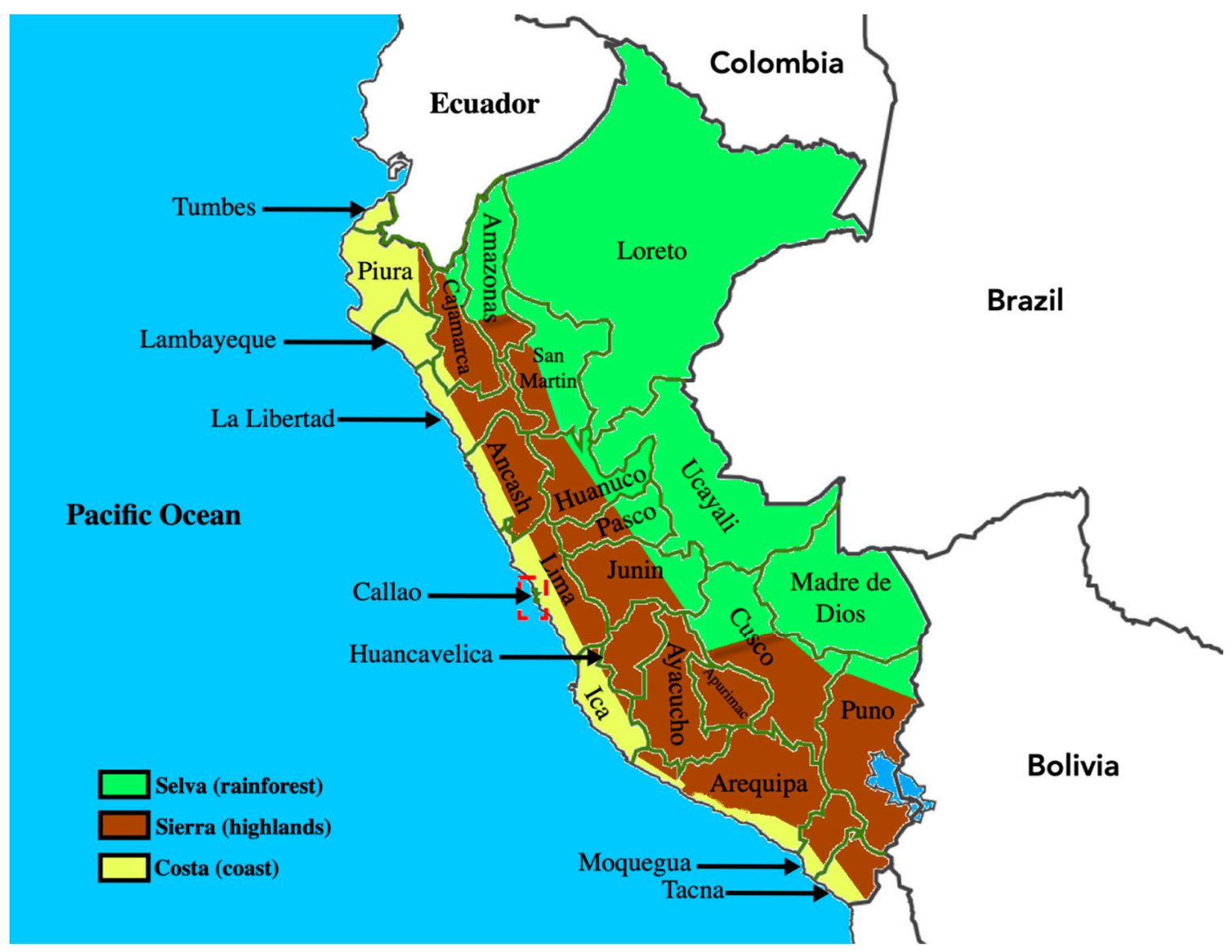

Figure 1. Map of Peru, showing its three geographical regions and 25 departments. ArcGIS 10.8.1 software (http:/ / www. esri.com/software/arcgis, accessed on 5 May 2021) was used to develop the map.

\section{Inclusion Criteria for Review}

The studies that were included in this comprehensive review consisted of scientific peer-reviewed works and governmental reports from Peru that focused on quantifying pesticide residues, heavy metals, and mycotoxins in produce grown in Peru. Scientific articles on heavy-metal contaminants in rivers in Peru were also included, given their potential as a source of heavy metals that can contaminate produce. The works that were considered employed analytical chemistry methods (e.g., gas or liquid chromatography and mass spectrometry) for evaluation of chemical contaminants. Relevant studies presented in academic theses were also included for this systematic review.

\section{Chemical Contaminants}

\subsection{Pesticide Residues in Produce}

Pesticides are broadly defined as plant protection products that eliminate unwanted pests, and are classified by the target pest (e.g., insecticides, herbicides, fungicides). These chemical substances can also be classified as natural or synthetic, with the latter being the most commonly used in farms. The use of pesticides in agriculture has contributed to reducing crop losses, and maintaining a steady yield of the product. Additionally, pesticides have been utilized in human medicine in the control of disease vectors (e.g., the Anopheles mosquito related to malaria). Although their utilization has been with the intention of promoting crop protection and productivity, their consistent use is known to affect human health.

The use of certain pesticides has been prohibited in Peru, and most other countries, because of their well-known potential adverse effects. Public awareness of pesticide 
toxicity was not achieved until the publication of the book Silent Spring by Rachel Carson in 1962. This book related the potential impacts of dichlorodiphenyltrichloroethane (DDT), an organochloride insecticide, on the environment, plants, animals, and human health. Silent Spring helped to create an environmental movement that led to the ban of DDT for agricultural purposes in the US and other nations. Peru, like other nations, has prohibited the use of organochloride insecticides (see Table S1) such as DDT since 1991 [24].

While the use of this pesticide class is illegal, there are other classes of harmful pesticides commonly used to date in Peru. Some examples include insecticides (e.g., organophosphates, carbamates, and pyrethroids), herbicides (e.g., paraquat), and fungicides (see Table S2). The Ministry of Agriculture and Irrigation (Ministerio de Agricultura y Riego, MINAGRI) reported an increase of 2.6 to 3.3 metric tons of imported pesticides to Peru from 2012 to 2016 [25]. This data is concerning, as agriculture is an important consumer sector of pesticides in Peru. Additionally, data on pesticide use suggests that increased productivity in the Costa region goes hand-in-hand with the higher use of pesticides in this area when compared with the other two regions (Table 2) [26]. The increases in pesticide application to boost production and meet consumer demands can result in a higher accumulation of the pesticide, or derivatives (termed "pesticide residues"), as the contaminated produce goes up the food chain.

Table 2. Percentage of pesticide use by every 100 farms in each region of Peru.

\begin{tabular}{ccccccc}
\hline Region & \multicolumn{2}{c}{ Chemical Insecticides } & \multicolumn{2}{c}{ Herbicides } & \multicolumn{2}{c}{ Fungicides } \\
\hline & $\begin{array}{c}\text { Farms } \\
\text { that Apply }\end{array}$ & $\begin{array}{c}\text { Farms that Do } \\
\text { Not Apply }\end{array}$ & $\begin{array}{c}\text { Farms } \\
\text { that Apply }\end{array}$ & $\begin{array}{c}\text { Farms that Do } \\
\text { Not Apply }\end{array}$ & $\begin{array}{c}\text { Farms } \\
\text { that Apply }\end{array}$ & $\begin{array}{c}\text { Farms that Do } \\
\text { Not Apply }\end{array}$ \\
\hline Coast & 67 & 33 & 55 & 45 & 52 & 48 \\
Sierra & 37 & 63 & 14 & 76 & 25 & 75 \\
Amazon & 16 & 84 & 29 & 71 & 86 \\
\hline
\end{tabular}

Few research studies have evaluated pesticide residues in Peruvian produce. Two studies showed that the use of the organophosphate methamidophos resulted in pesticide residues in tomatoes and potatoes available in different markets in Lima [27,28]. The studies found that $9 / 20(45 \%)$ sampled potatoes and 1/25 (4\%) sampled tomatoes exceeded the maximum residue limit (MRL) for methamidophos $(0.05 \mathrm{mg} / \mathrm{kg})$ in that commodity (Table 3). In Peru, the MRLs of pesticides residues were established under the legislation $\mathrm{N}^{\circ} 1006-2016 / \mathrm{MINSA}$, and when values for a given specific pesticide are not defined, the Codex Alimentarius is used as reference [29].

Table 3. Levels of pesticide residues in Peruvian produce. Adapted from multiple studies.

\begin{tabular}{|c|c|c|c|c|}
\hline Produce & Pesticide Residue & Mean Concentration (mg/kg) & MRL $^{1}$ & Reference \\
\hline Potatoes & Methamidophos & 2.7 & 0.05 & [27] \\
\hline Mandarin & Thiabendazole & 5.1 & 5 & [30] \\
\hline Tomato & Methamidophos & 1 & 1 & [28] \\
\hline Peas & Fenhexamid & 0.16 & 0.05 & \\
\hline Table grapes & Methomyl & 0.12 & 0.05 & [30] \\
\hline
\end{tabular}

${ }^{1}$ Maximum residue limit (MRL). Values according to the National Service of Agrarian Health agency [29].

Governmental authorities in Peru have reported chemical contamination of produce. The SENASA agency reported the presence of pesticide residues and mycotoxins in various fruits and vegetables obtained from markets of multiple departments across Peru (Table 4). The SENASA reports from 2011-2019 show that the number of samples that exceeded the MRL for pesticide residues was $\geq 10 \%$ per year [31-39]. The majority of noncompliant samples were associated with values above the MRL of chlorpyrifos (0.05-20 mg/kg), cypermethrin $(0.05-20 \mathrm{mg} / \mathrm{kg})$, methamidophos $(0.01-1 \mathrm{mg} / \mathrm{kg})$, and tebuconazole $(0.05-10 \mathrm{mg} / \mathrm{kg})$ in every report since 2012. Tacna and La Libertad were the departments that were more 
frequently linked to noncompliant samples. These SENASA reports are the most comprehensive reports on pesticide-residue contamination within Peru, and offer insight that the previously mentioned pesticides tend to be problematic in produce.

Table 4. Chemical compliance of samples of plant origin monitored from 2011 to 2019 in Peru. Table adapted from annual reports by the National Service of Agrarian Health agency [31-39].

\begin{tabular}{|c|c|c|c|c|}
\hline \multirow{2}{*}{ Year } & \multirow{2}{*}{ Total } & \multicolumn{2}{|c|}{$\mathbf{N}^{\circ}$ of Noncompliant Samples (\%) } & \multirow{2}{*}{ Departments with $>40 \%$ Noncompliant Samples } \\
\hline & & Pesticide Residues & Mycotoxins $^{1}$ & \\
\hline 2011 & 252 & $73(34.5)$ & $14 / 42(33.3)$ & Cajamarca, Ica, Piura, Tacna. \\
\hline 2012 & 725 & $193(26.7)$ & $8 / 62(12.9)$ & Tacna, La Libertad \\
\hline 2013 & 705 & $175(24.8)$ & $19 / 74(25.7)$ & La Libertad, Tacna \\
\hline 2014 & 756 & $228(30.2)$ & $6 / 84(7.14)$ & Arequipa \\
\hline 2015 & 733 & $216(29.5)$ & $11 / 84(13.1)$ & Piura \\
\hline 2016 & 738 & $199(27.0)$ & $2 / 43(4.65)$ & La Libertad \\
\hline 2017 & 761 & $76(10.0)$ & $6 / 77(7.79)$ & None \\
\hline 2018 & 793 & 105 (13.2) & $2 / 79(2.53)$ & None \\
\hline 2019 & 1779 & \multicolumn{2}{|c|}{$373(21)^{2}$} & $\begin{array}{l}\text { Amazonas, Arequipa, Apurimac, Ayacucho, Junin, Ica, } \\
\text { La Libertad, Lambayeque, Lima, Piura, Tacna }\end{array}$ \\
\hline
\end{tabular}

Varieties of produce sampled annually included Brazil nut, paprika, olive, grape, tomato, avocado, mango, orange, mandarin, lemon, asparagus, onion, coffee bean, banana, artichoke, and lima bean. ${ }^{1}$ Mycotoxin analysis assessed total aflatoxins (A1, A2, G1, G2) and ochratoxin A, only in paprika and Brazil nuts. ${ }^{2}$ No distinction was made, and number includes high levels of pesticide residues, mycotoxins, and heavy metals (arsenic, cadmium, and lead).

There has also been Peruvian produce found to have breached the MRL of pesticides in the receiving country. The crops included lettuce, paprika, quinoa, peas, and mandarins [40] These findings were further confirmed by reports that described multiple agricultural Peruvian imports into the US that were detained due to contamination with pesticide residues (e.g., chlorpyrifos and methamidophos), or mycotoxin contamination [41]. A European study focused on fruits and vegetables from different South American countries commercially available in various Nordic countries also reported contaminated produce [30]; among the produce varieties sampled from Peru, 4/46 (8.7\%) exceeded the MRL for two fungicides and one carbamate insecticide (Table 3). Even though Peruvian products had a low sample size, it is concerning that the percentage of positive samples exceeding the MRL for the pesticides was comparable to that of Colombia $(n=81,10 \%$ positive) or Brazil ( $n=233,13 \%$ positive), which both had a larger sample size.

The inappropriate use of pesticides is a likely cause of their increased levels in produce. A study in China found that if the fungicide chlorothalonil was applied on cabbage based on their recommended frequency preharvest, the residual amount did not exceed the MRL $(1 \mathrm{mg} / \mathrm{kg})$ [42]. Another study in Chile found that $32 / 118(27 \%)$ of sampled leafy greens exceeded the domestic MRL for cypermethrin $(0.70 \mathrm{mg} / \mathrm{kg})$, chlorothalonil $(0.01 \mathrm{mg} / \mathrm{kg})$, chlorpyrifos $(0.05 \mathrm{mg} / \mathrm{kg})$, and methamidophos $(0.01 \mathrm{mg} / \mathrm{kg})$ [43]. The authors of the Chilean study attributed these findings to the high frequency of applications in North Central agricultural farms of Chile. These comparisons offer a plausible explanation to the recurrent MRL breaches of certain pesticides (e.g., chlorpyrifos, methamidophos) in Peruvian crops.

Although most reports on pesticide residues are focused on produce for export purposes, there are scant studies on other crop varieties consumed internally. This excludes crop varieties such as blueberries, lucuma, leafy greens, sprouts, and quinoa, which are common components of the Peruvian diet. It could be argued that since there is no governmental push to monitor the previously mentioned crops, then growers have no increased incentive to implement better agricultural practices. The absence of data from many crops for internal consumption sheds light on a food-safety loophole, which can potentially affect their consumers. 


\subsection{Heavy Metals in Produce}

Heavy metals are hazardous contaminants in living ecosystems. Some characteristics of these trace elements that make them challenging to deal with include their low biodegradability, long persistence in the environment, and ability to accumulate in living beings and subsequently cause a negative effect in the host. Their presence in produce is generally attributed to the entry of heavy metals either from natural mineral sources or anthropogenic activities (pesticides, contaminated irrigation water) into environmental matrices (soil, water, and air), which are in direct contact with plants [44]. Plants are limited in their mechanisms of nutrient absorption and cannot distinguish between the nutrients being absorbed [45]. Therefore, the degree of pollution in the environment can dictate the likelihood of plant-heavy-metal interactions. As a consequence of these interactions, the consumption of the harvested crop is a major risk of human exposure to heavy metals [46].

The rapid industrialization and a growing population contribute to heavy-metal pollution in Peru. The expansion of mining, an activity that accounts for $14 \%$ of Peru's GDP and about $60 \%$ of exports, is an important source of heavy-metal contamination [47]. Mining practices release over 13 billion $\mathrm{m}^{3}$ of effluents annually, creating undesirable stress in rivers and other sources of water that are used for crop irrigation [48]. These practices result in contamination of soil and water with arsenic (As), cadmium $(\mathrm{Cd})$, copper $(\mathrm{Cu})$, lead $(\mathrm{Pb})$, and/or zinc $(\mathrm{Zn})$ - heavy metals that are often found in increased amounts in produce [49].

It has been estimated that about 1.6 million people ( $5 \%$ of Peru's population) live within $5 \mathrm{~km}$ of active or historical mining sites, and human activity in proximity to Peruvian mines is primarily agricultural [50]. Thus, the high risk of pollution by mining effluents threatens the food safety of nearby crops. For example, one European risk-assessment study on daily heavy-metal intake in drinking water and foods found that $\mathrm{As}$ and $\mathrm{Pb}$ levels were elevated in the diets of the population that was closer to a gold mine in Cajamarca, Peru [51]. Additionally, greater use of agrochemicals (pesticides and fertilizers), or higher gas emissions from the use of leaded gasoline, may increase the levels of these trace elements in produce [52,53].

Some primary studies quantified heavy-metal contamination in produce in Peru, and these are summarized in Table 5. A group from the National University of Piura conducted a study to measure the levels of several heavy metals in 10 different vegetable varieties in the city of Piura [54]. Results from this study showed that all the evaluated vegetables registered values exceeding the maximum contaminant limit (MCL) for $\mathrm{Pb}(0.1 \mathrm{mg} / \mathrm{kg})$. The levels of As were also noncompliant in cilantro and lettuce $(>0.1 \mathrm{mg} / \mathrm{kg})$. The work focused on produce grown in the city of Trujillo, which has the greatest production of vegetables in the north of Peru. Similarly, commercially available lettuce has also been found to exceed the MCL for $\mathrm{Pb}$ at $0.3 \mathrm{mg} / \mathrm{kg}$ [55].

Table 5. Heavy-metal contamination in produce grown in Peru.

\begin{tabular}{|c|c|c|c|c|c|c|c|c|}
\hline \multirow{2}{*}{ Produce } & \multicolumn{6}{|c|}{ Mean Concentration (mg/kg) } & \multirow{2}{*}{ Origin } & \multirow{2}{*}{ Reference } \\
\hline & $\mathbf{P b}$ & $\mathrm{Zn}$ & $\mathrm{Cu}$ & $\mathrm{Cd}$ & As & $\mathrm{Cr}$ & & \\
\hline Apple & 0.10 & 2.4 & 0.6 & BDL & 0.05 & NM & Lima & [56] \\
\hline Avocado & $0.18^{a}$ & 2.9 & 0.32 & $\mathrm{BDL}$ & $\mathrm{BDL}$ & NM & $\begin{array}{l}\text { Morropon, } \\
\text { Chulucanas }\end{array}$ & [54] \\
\hline Barley & BDL & 60 & 19 & NM & 0.14 & NM & Junin & [57] \\
\hline Cabbage & $9.3^{\mathrm{a}}$ & 1.1 & BDL & BDL & BDL & NM & Trujillo & [54] \\
\hline
\end{tabular}


Table 5. Cont

\begin{tabular}{|c|c|c|c|c|c|c|c|c|}
\hline \multirow{2}{*}{ Produce } & \multicolumn{6}{|c|}{ Mean Concentration (mg/kg) } & \multirow{2}{*}{ Origin } & \multirow{2}{*}{ Reference } \\
\hline & $\mathbf{P b}$ & $\mathrm{Zn}$ & $\mathrm{Cu}$ & $\mathrm{Cd}$ & As & $\mathrm{Cr}$ & & \\
\hline \multirow{10}{*}{ Cacao bean } & NM & NM & NM & 2.5 & NM & NM & Huanuco & \multirow{9}{*}{ [59] } \\
\hline & $2.2^{\mathrm{a}}$ & 52 & 30 & 0.97 & NM & 4.83 & Amazonas & \\
\hline & 1.0 & 44 & 26 & 0.77 & NM & 1.0 & Cajamarca & \\
\hline & 1.0 & 40 & 19 & 0.17 & NM & BDL & Cuzco & \\
\hline & $1.5^{\mathrm{a}}$ & 37 & 25 & 0.64 & NM & 1.0 & Huanuco & \\
\hline & $2.7^{\mathrm{a}}$ & 47 & 28 & 0.41 & NM & BDL & Junin & \\
\hline & $3.8^{\mathrm{a}}$ & 59 & 27 & 1.6 & NM & 1.0 & Piura & \\
\hline & $1.7^{\mathrm{a}}$ & 44 & 27 & 0.79 & NM & 1.0 & San Martin & \\
\hline & $2.8^{\mathrm{a}}$ & 52 & 26 & 1.8 & NM & 1.0 & Tumbes & \\
\hline & $1.7^{\mathrm{a}}$ & 74 & NM & 0.96 & NM & NM & Ucayali, Huanuco & {$[60]$} \\
\hline Carrot & $17^{\mathrm{a}}$ & 6.6 & BDL & BDL & BDL & NM & Trujillo & [54] \\
\hline \multirow{2}{*}{ Cassava root } & $5.8^{\mathrm{a}}$ & NM & NM & 0.039 & $3.0^{\mathrm{a}}$ & NM & Hualgayoc & [61] \\
\hline & $0.13^{\mathrm{a}}$ & NM & NM & 0.05 & NM & NM & Junin & [62] \\
\hline Cauliflower & $4.4^{\mathrm{a}}$ & 2.4 & $\mathrm{BDL}$ & BDL & BDL & NM & Trujillo & [54] \\
\hline Chili pepper & $11^{\mathrm{a}}$ & 3.0 & 0.32 & BDL & BDL & NM & Trujillo & [54] \\
\hline \multirow{2}{*}{ Cilantro } & $3.2^{\mathrm{a}}$ & 4.0 & 0.89 & BDL & $2.050^{\mathrm{a}}$ & NM & Trujillo & [54] \\
\hline & 0.050 & NM & NM & 0.025 & 0.05 & 0.031 & Arequipa & [63] \\
\hline Corn & BDL & 37 & 2.1 & NM & 0.0785 & NM & Junin & [57] \\
\hline \multirow[t]{2}{*}{ Green pea } & $2.0^{\mathrm{a}}$ & 5.5 & 1.7 & BDL & BDL & NM & Trujillo & [54] \\
\hline & $4.2^{\mathrm{a}}$ & 2.5 & 0.63 & BDL & $0.900^{\mathrm{a}}$ & NM & Trujillo & [54] \\
\hline \multirow[t]{2}{*}{ Lettuce } & $2.1^{\mathrm{a}}$ & NM & NM & 0.1 & NM & NM & Sierra & [55] \\
\hline & $0.37^{\mathrm{a}}$ & NM & NM & 0.066 & NM & NM & Costa & \\
\hline Lime & $0.12^{\mathrm{a}}$ & 1.5 & $\mathrm{BDL}$ & 0.065 & BDL & NM & Trujillo & [56] \\
\hline Mango & 0.087 & 1.5 & BDL & BDL & BDL & NM & Chulucanas & [56] \\
\hline \multirow[t]{2}{*}{ Corn } & 0.010 & NM & NM & BDL & 0.030 & NM & Arequipa & [64] \\
\hline & $1.5^{\mathrm{a}}$ & 0.70 & 0.23 & 0.023 & BDL & NM & Trujillo & [54] \\
\hline \multirow[t]{2}{*}{ Onion } & NM & NM & NM & $0.060^{\mathrm{a}}$ & 0.042 & NM & Arequipa & [65] \\
\hline & NM & NM & NM & 0.040 & 0.040 & NM & Trujillo, Huaral & [65] \\
\hline Orange & 0.10 & 2.4 & BDL & BDL & BDL & NM & Sullana, Lima & [56] \\
\hline Papaya & 0.090 & 2.0 & 0.63 & BDL & 0.20 & NM & Sullana & [56] \\
\hline Plantain & 0.090 & 1.0 & BDL & BDL & BDL & NM & Chulucanas & [56] \\
\hline \multirow[t]{2}{*}{ Plum } & $0.20^{a}$ & 2.5 & 1.1 & 0.023 & BDL & NM & Piura & [56] \\
\hline & 0.10 & NM & NM & 0.029 & 0.00040 & NM & Lima & [66] \\
\hline \multirow[t]{2}{*}{ Potato } & BDL & NM & NM & $0.31^{\mathrm{a}}$ & NM & NM & Cajamarca & [67] \\
\hline & $0.41^{\mathrm{a}}$ & 18 & NM & 0.042 & 0.13 & NM & Junin & [68] \\
\hline Quinoa & 0.040 & NM & NM & 0.020 & 0.060 & NM & Arequipa & [64] \\
\hline \multirow{2}{*}{ Rice } & 0.086 & 13 & 4.0 & 0.33 & $>0.20^{\mathrm{a}}$ & 0.151 & Tumbes & [69] \\
\hline & 0.040 & NM & NM & 0.11 & 0.17 & NM & Arequipa & [64] \\
\hline Strawberry & $0.20^{\mathrm{a}}$ & 3.5 & 0.30 & BDL & BDL & NM & Trujillo & [56] \\
\hline Tomato & $1.9^{\mathrm{a}}$ & 1.4 & 1.1 & 0.065 & BDL & NM & Trujillo & [54] \\
\hline Turnip & $5.3^{\mathrm{a}}$ & 2.7 & 0.59 & BDL & BDL & NM & Trujillo & [54] \\
\hline Watermelon & 0.090 & 0.70 & BDL & BDL & BDL & NM & Trujillo & [56] \\
\hline
\end{tabular}

${ }^{a}$ Denotes values exceeding the maximum contaminant limit for the specific heavy metal in the specific produce variety. BDL, below detection limit; NM, not measured.

Mining activities can influence the presence of heavy metals in agricultural crops. A study in Cajamarca showed that all sampled potatoes $(n=40)$ were contaminated with Cd (mean value of $0.31 \mathrm{mg} / \mathrm{kg}$ ), exceeding its MCL at $0.1 \mathrm{mg} / \mathrm{kg}$ [67] The finding was meaningful, as the potatoes were grown in proximity to the Yanacocha mine, South America's largest gold mine. This mine influences two of the rivers, the water of which was used to irrigate the potato crops. Another study found potatoes in Junin showed levels of $\mathrm{Pb}$ at $0.41 \mathrm{mg} / \mathrm{kg}$ (MCL at $0.1 \mathrm{mg} / \mathrm{kg}$ ) [68] The authors explained that mining was a likely source of this contamination. Similarly, other studies in Chile, China, and Slovakia reported that produce grown near a mining operation had noncompliant concentrations of $\mathrm{As}, \mathrm{Pb}$, and $\mathrm{Cd}$ [70-72]. These findings supported the importance of understanding the risk of contamination of produce grown close to mining activities. 
These studies, although useful in bringing more attention to the issue of heavy metals, do not describe the complete status of heavy-metal contamination in produce throughout Peru. In an effort to address this knowledge gap, SENASA began to include analyses of As, $\mathrm{Cd}$, and $\mathrm{Pb}$ in produce in its annual reports in $2019[39,73]$. This may indicate a trend toward increased governmental awareness with regard to the potential chemical contaminants to which produce is exposed in Peru. However, there is also room for improvement, especially in transparency, as the 2019 report did not differentiate the contribution of specific chemical classes in noncompliant samples [39].

\subsection{Mycotoxin Contamination in Produce}

Mycotoxins are naturally occurring toxic secondary metabolites produced by fungi (e.g., Aspergillus, Fusarium and Penicillium), and are a common contaminant in food commodities around the world. Approximately 300 mycotoxins have been characterized, but the more common food contaminants include aflatoxins (AT), ochratoxins (OT), patulin (PT), and fumonisins (FM) [74]. Mycotoxin contamination can occur throughout the entire production process, from pre- to postharvest. Warm temperatures $\left(20-28{ }^{\circ} \mathrm{C}\right)$ and high humidity are conditions that tend to favor the growth of mesophilic mold, resulting in greater toxin production [75]. Thus, poor drying and inappropriate storage conditions during postharvest activities will increase the risk of mycotoxin contamination.

There are a few studies that evaluated mycotoxin contamination in produce. An early study detected OT A at a mean level of $37.1 \mu \mathrm{g} / \mathrm{kg}$ in paprika $(n=130)$, and exceeding its MCL at $15 \mu \mathrm{g} / \mathrm{kg}$ [75]. Similarly, another study found that red chili peppers from Cusco were contaminated with both AT B1 and OT A [76]. This study showed that the mean concentration of OT A $(29 \mu \mathrm{g} / \mathrm{kg})$ was also above the MCL for OT A $(15 \mu \mathrm{g} / \mathrm{kg})$. Another project in the same crop reported that AF B1 contaminated 2/4 (50\%) of the samples, yet at levels below the MCL established by the Codex Alimentarius at $10 \mu \mathrm{g} / \mathrm{kg}$ for aflatoxins [77]. A recent study reported that Peruvian purple maize $(n=82)$ was commonly contaminated with both AT B1 and FM (B1 + B2), with mean values of $2.1 \mu \mathrm{g} / \mathrm{kg}$ and $2.6 \mathrm{mg} / \mathrm{kg}$, respectively [78]. While the levels of either AT and FM did not exceed the MCL established by the Codex Alimentarius, the levels of FM were above the MCL set by the EU at $1 \mathrm{mg} / \mathrm{kg}$. The findings on FM indicated an area for improvement if Peru wants to potentiate its exports of maize to the EU. A similar study in Brazil found that 14/148 maize samples had a noncompliant concentration for FM (MCL set at $5 \mathrm{mg} / \mathrm{kg}$ in that country) [79]. The importance of these findings is related to chili peppers and corn maize being integral components in the Peruvian diet, and that also one of the major problems during the production of these crops is mycotoxin contamination [80].

The byproducts of produce are also at risk of mycotoxin contamination. For example, one Peruvian detected PT in 2/6 (33\%) samples of the commercially available apple juice in Lima, using thin-layer chromatography [81]. This same work also detected the same toxin in 3/12 (25\%) visibly damaged apples sampled from the market. The authors corroborated these findings by confirming the presence of Penicillium molds, a common producer of PT, in the apples. Since putrid apples may be used for juice or cider production, the Food and Agriculture Organization recommends that unfit apples are removed to avoid the likelihood of PT in apple byproducts [82].

The SENASA agency has also reported the levels of mycotoxins in two crop varieties (Table 4). The conducted analytes include total AT (B1, B2, G1, G2) and OT A only in paprika and Brazilian nuts. The number of noncompliant samples decreased from 33.3\% (14/42) in 2011 to $2.53 \%$ (2/79) in 2018, which was an indication of improvements in the storage conditions of these commodities over time. However, these analyses of mycotoxins led by the government should be more inclusive of other crops, since paprika and Brazil nuts are not the only crops at risk of contamination with mycotoxins, and should not exclude other economically important crops like corn and beans [83,84]. 


\section{Water and Chemical Contaminants}

The water that is utilized for irrigation is a potential source of chemical pollutants. Runoffs of the mining and agriculture sectors are responsible for heavy-metal and pesticide contamination of different bodies of superficial water (e.g., lakes, rivers) [85]. Moreover, these two sectors use approximately $87 \%$ of the total water used annually, and only about $25 \%$ of operation effluents are treated $[85,86]$, thus increasing the risk of poorly treated water making it back into rivers and streams, and contributing both microbiological and chemical contaminants that can enter the food chain.

Only a few studies have looked into pesticide residues in water sources $[87,88]$. Metabolites of DDT were reported at concentrations of $0.010-0.12 \mu \mathrm{g} / \mathrm{L}$ in rivers in Tarapoto, Peru [87]. Another study detected traces of chlorpyrifos $(0.69 \mathrm{ng} / \mathrm{L})$ and DDT derivatives $(0.0059 \mathrm{ng} / \mathrm{L})$ in the water of Alto Mayo, Peru [88] The presence of DDT derivatives in both studies could be attributed to either illegal use or its low biodegradability since the time it was banned in the 1990s. On the other hand, the presence of chlorpyrifos, an approved organophosphate insecticide, may be linked to its frequent application during agricultural activities.

In contrast to the limited studies of pesticide residues in water, there are numerous works that report the presence of heavy metals in water, and these are summarized in Table 6. The most frequent elements in water sources with noncompliant values included $\mathrm{As}, \mathrm{Cd}$, and $\mathrm{Pb}$. For example, the Rimac River was reported to have high concentrations of $0.27 \mathrm{mg} / \mathrm{L}$ in $\mathrm{Pb}$ and $0.016 \mathrm{mg} / \mathrm{L}$ in Cd, exceeding Peruvian MCL in irrigation water [89]. The Rimac River is important for the densely populated departments of Lima and Callao, as it serves many purposes including farming, mining, power, and drinking water. Another study reported that irrigation canals that sourced water from the Mantaro River in Junin showed a concentration of $0.18 \mathrm{mg} / \mathrm{L}$ As [90]. Similarly, the Cunas sub-basin, a tributary of the Mantaro River, has also been shown to have exceeding levels of As, at $0.60 \mathrm{mg} / \mathrm{L}$ [91]. Chemical contamination has been a problem in these two rivers since initial reports in 1986 [92]. Since agricultural crops are irrigated with water from these rivers, this indicates that crops in Junin and Lima are at risk of heavy-metal contamination. Although increasing sources of water is a growing necessity throughout Peru, so is ensuring access to higherquality water.

Table 6. Irrigation water contaminated with heavy metals in Peru. Values shown are mean or ranges.

\begin{tabular}{|c|c|c|c|}
\hline Source & Location & Heavy-Metal Levels & Reference \\
\hline \multirow[t]{2}{*}{ Tumbes River } & Tumbes & $0.016 \mathrm{mg} / \mathrm{L} \mathrm{As}$ & [69] \\
\hline & \multirow{5}{*}{ Junin } & $0.60 \mathrm{mg} / \mathrm{L} \mathrm{As}^{\mathrm{a}}$ & \\
\hline \multirow{4}{*}{ Cunas sub-basin } & & $19 \mathrm{mg} / \mathrm{L} \mathrm{Mn}^{\mathrm{a}}$ & \\
\hline & & $0.023 \mathrm{mg} / \mathrm{L} \mathrm{Cd}^{\mathrm{a}}$ & [91] \\
\hline & & $12 \mathrm{mg} / \mathrm{L} \mathrm{Zn^{a }}$ & \\
\hline & & $0.010 \mathrm{mg} / \mathrm{L} \mathrm{Cd}$ & \\
\hline \multirow{4}{*}{ (Irrigation canals of) Mantaro River } & \multirow[t]{2}{*}{ Junin } & $51 \mathrm{mg} / \mathrm{L} \mathrm{Fe}$ & \\
\hline & & $2.1 \mathrm{mg} / \mathrm{L} \mathrm{Mn}^{\mathrm{a}}$ & \\
\hline & \multirow[t]{2}{*}{ Junin } & $0.18 \mathrm{mg} / \mathrm{L} \mathrm{As}^{\mathrm{a}}$ & [90] \\
\hline & & $0.47 \mathrm{mg} / \mathrm{L} \mathrm{As}^{\mathrm{a}}$ & \\
\hline \multirow{6}{*}{ Rimac River } & \multirow{6}{*}{ Lima } & $0.029 \mathrm{mg} / \mathrm{L} \mathrm{Cd}^{\mathrm{a}}$ & [93] \\
\hline & & $21 \mathrm{mg} / \mathrm{L} \mathrm{Mn}^{\mathrm{a}}$ & \\
\hline & & $0.27 \mathrm{mg} / \mathrm{L} \mathrm{Pb}^{\mathrm{a}}$ & \\
\hline & & $0.016 \mathrm{mg} / \mathrm{L} \mathrm{Cd}^{\mathrm{a}}$ & [89] \\
\hline & & $0.38 \mathrm{mg} / \mathrm{L} \mathrm{Cu}^{\mathrm{a}}$ & \\
\hline & & $0.15 \mathrm{mg} / \mathrm{L} \mathrm{Pb}^{\mathrm{a}}$ & \\
\hline \multirow[t]{3}{*}{ Chillon River } & \multirow[t]{3}{*}{ Callao } & $0.012 \mathrm{mg} / \mathrm{L} \mathrm{Cd}^{\mathrm{a}}$ & [89] \\
\hline & & $0.31 \mathrm{mg} / \mathrm{L} \mathrm{Cu}^{\mathrm{a}}$ & \\
\hline & & $0.076 \mathrm{mg} / \mathrm{L} \mathrm{Pb}^{\mathrm{a}}$ & \\
\hline \multirow[t]{2}{*}{ Lurin River } & \multirow[t]{2}{*}{ Lima } & $0.018 \mathrm{mg} / \mathrm{L} \mathrm{Cd}^{\mathrm{a}}$ & [89] \\
\hline & & $0.18 \mathrm{mg} / \mathrm{L} \mathrm{Cu}$ & \\
\hline
\end{tabular}


Table 6. Cont.

\begin{tabular}{|c|c|c|c|}
\hline Source & Location & Heavy-Metal Levels & Reference \\
\hline Grande River & Cajamarca & $0.25 \mathrm{mg} / \mathrm{L} \mathrm{Pb}^{\mathrm{a}}$ & [94] \\
\hline \multirow[t]{2}{*}{ Nanay River } & Loreto & $0.11 \mathrm{mg} / \mathrm{L} \mathrm{Pb}^{\mathrm{a}}$ & [95] \\
\hline & & $0.16 \mathrm{mg} / \mathrm{L} \mathrm{Cd}^{\mathrm{a}}$ & \\
\hline Ananea River & Puno & $\begin{array}{l}6.3 \mathrm{mg} / \mathrm{L} \mathrm{As}^{\mathrm{a}} \\
1.4 \mathrm{mg} / \mathrm{L} \mathrm{Pb}^{\mathrm{a}} \\
0.99 \mathrm{mg} / \mathrm{L} \mathrm{Cr}^{\mathrm{a}}\end{array}$ & [96] \\
\hline Tambo River & & $0.20 \mathrm{mg} / \mathrm{L} \mathrm{As}^{\mathrm{a}}$ & \\
\hline Quilca River & Arequipa & $0.11 \mathrm{mg} / \mathrm{L} \mathrm{Pb}^{\mathrm{a}}$ & [97] \\
\hline Camana River & & $\begin{array}{c}0.050 \mathrm{mg} / \mathrm{L} \mathrm{Pb} \\
0.0012 \mathrm{mg} / \mathrm{L} \mathrm{Pb}\end{array}$ & \\
\hline \multirow[t]{2}{*}{ Huatanay River } & Cusco & $0.0036 \mathrm{mg} / \mathrm{L} \mathrm{As}$ & [98] \\
\hline & & $0.0010 \mathrm{mg} / \mathrm{L} \mathrm{Cr}$ & \\
\hline Caychihue River & Madre de Dios & $\begin{array}{l}0.20 \mathrm{mg} / \mathrm{L} \mathrm{Pb}^{\mathrm{a}} \\
0.20 \mathrm{mg} / \mathrm{L} \mathrm{As}^{\mathrm{a}}\end{array}$ & [99] \\
\hline Moche River & La Libertad & $\begin{array}{c}0.0050-0.91 \mathrm{mg} / \mathrm{L} \mathrm{Pb}^{\mathrm{a}} \\
0.0010-0.11 \mathrm{mg} / \mathrm{L} \mathrm{A} \mathrm{s}^{\mathrm{a}} \\
0.0010-0.20 \mathrm{mg} / \mathrm{L} \mathrm{Cd}^{\mathrm{a}} \\
0.045-1.2 \mathrm{mg} / \mathrm{L} \mathrm{Cu}^{\mathrm{a}}\end{array}$ & [92] \\
\hline
\end{tabular}

\section{Chemical Contaminants and Public Health}

It is estimated that chemical contamination, from all sources including food, is responsible for 4.9 million deaths and 86 million disability-adjusted life years per annual basis around the world [100]. Chemical contaminants in foods have serious human health consequences, ranging from minor stomach problems to death. The specific health effects for heavy metals, mycotoxins, and pesticides have been described elsewhere [74,101,102]. These contaminants tend to be associated with a complex array of health manifestations based on dose, ranging from acute (e.g., nausea, vomiting, tremors) to more chronic (e.g., suppression of immunity, cancer, neuropathy, and organ damage) and lethal effects.

Reports linking pesticide residues as the causative agent of foodborne outbreaks in Peru were associated with acute intoxications. These poisonings entailed three massive foodborne outbreaks that involved a total of 255 individuals and led to 36 deaths. The first outbreak occurred in 1999 in Tauccamarca, Cusco, where 50 children in a school were intoxicated after consuming a powdered-milk substitute tainted with parathion [103]. This exposure led to 24 deaths, while the remaining 26 survived and suffered from dizziness and convulsions [104]. In 2011, 97 children were poisoned, three of whom died after eating lentils and rice contaminated with carbofuran at a school in Cachachi, Cajamarca [103]. Another outbreak involving parathion occurred in 2018 at Paucar del Sara Sara, Ayacucho, affecting 111 people, and killing 9 of those who ate mote soup at a wake [105]. It is alarming that two of these outbreaks involved parathion, an extremely hazardous (or Class Ia according to the WHO) organophosphate banned from use in Peru since 1998. The parathion tragedies were 20 years apart, yet the most recent outbreak emphasized that law enforcement regarding this pesticide has not been adequate and requires attention. This growing necessity for law enforcement is especially true, as parathion and other forbidden pesticides can still be purchased without a technical prescription in Peru [104].

Another type of pesticide intoxication indirectly related to produce food safety is that of occupational poisoning. The Ministry of Health (Ministerio de Salud, MINSA) reported that more than 2000 cases of acute poisoning (symptoms including headaches, temporary loss of vision, loss of consciousness, and dizziness) have occurred annually since 2016 [106]. It is likely that such poisonings were due to pesticide applicators not following the instructions on the labels of pesticide bottles. This hypothesis is supported by multiple Peruvian surveys, which showed that at least $50 \%$ of intoxications were due to mishandling of methamidophos, a highly hazardous organophosphate insecticide [107-109]. These intoxications occurred when applicators either failed to read the instructions or did not 
have the appropriate protective equipment to apply pesticides. Following the label is critical, as it relays information on what to wear when applying pesticides, as well as on the frequency and dosing of application, which are key to not exceed the MRLs as described above.

Acute heavy-metal intoxications have also been reported, but from all sources and not only from food. It was recorded that more than 6000 people were poisoned by heavy metals throughout Peru in 2018 (Figure 2). As discussed earlier, heavy metals are problematic in Junin and Lima, but also in Pasco and Callao, accounting for more than $96 \%$ of the total cases per year [110]. One study agreed with these trends, as it evaluated the $\mathrm{Pb}$ blood levels of pregnant women from the metallurgic city of La Oroya, Junin [111]. It was found that maternal blood $\mathrm{Pb}$ levels from 24/30 (80\%) participants were above $10 \mu \mathrm{g} / \mathrm{dL}$, putting mothers at a higher risk of spontaneous abortion [112,113]. Another study of 346 children from the same city found that only about $0.9 \%$ of the children had blood $\mathrm{Pb}$ levels under the recommended $10 \mu \mathrm{g} / \mathrm{dL}$, but children with exceeding levels of $\mathrm{Pb}$ did not receive continued monitoring [114]. This was in line with the MINSA report, which showed that children account for more than $80 \%$ of the cases of acute toxicity [106].

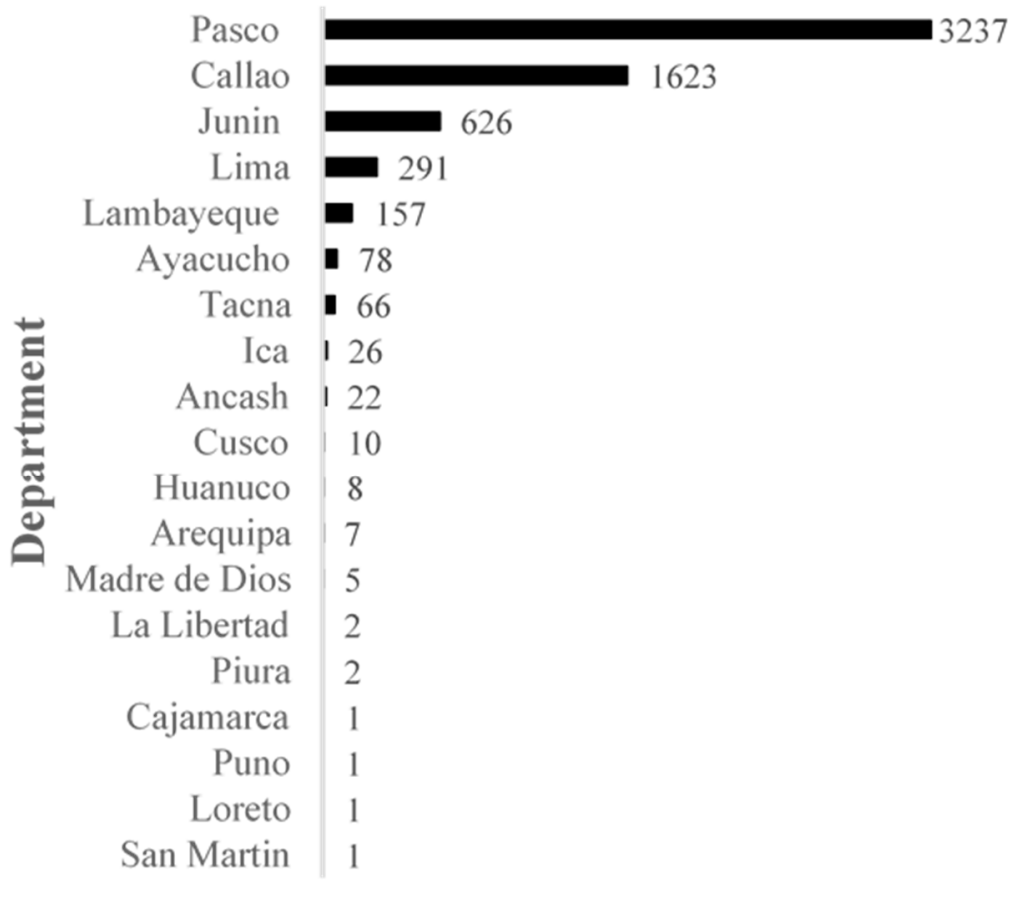

\section{$\mathrm{N}^{\circ}$ of cases}

Figure 2. Number of acute heavy-metal-related intoxications in Peru in 2018. Data adapted from a report by the Ministry of Health (MINSA, 2019b).

Lead toxicity has a long history as a critical issue in Peru, granting it the status of the leading country with the highest number of $\mathrm{Pb}$ intoxications in children in the Americas. Approximately 867,968 children ( 10\%) have blood Pb levels above $10 \mu \mathrm{g} / \mathrm{dL}$, the Peruvian reference value, and 7,132,941 children ( $84 \%$ ) have blood $\mathrm{Pb}$ levels above $5 \mu \mathrm{g} / \mathrm{dL}$, the US Centers for Disease Control reference value [115]. Blood Pb levels above $10 \mu \mathrm{g} / \mathrm{dL}$ have been previously demonstrated to lower cognitive abilities in children of ages 6 to 9 in Callao [116], thus suggesting that $\mathrm{Pb}$ exposure can affect areas of the brain and contribute to cognitive decline. Furthermore, as the values of blood $\mathrm{Pb}$ levels go up, so does the risk of death. This was clearly shown in a study from Chile, which detailed the case of a girl with a blood $\mathrm{Pb}$ concentration at $104 \mu \mathrm{g} / \mathrm{dL}$ [117]. Consequently, the girl died from symptoms related to severe anemia. This case aligned with severe $\mathrm{Pb}$ toxicity, described as when blood $\mathrm{Pb}$ levels are higher than $70 \mu \mathrm{g} / \mathrm{dL}$ [118]. The Chilean case motivated investigations 
that pinpointed consumption of wheat flour that was contaminated with $\mathrm{Pb}$ during milling as the source of the issue, and the batch of wheat flour was destroyed. This highlights the importance of appropriate follow-up in medical cases that could help prevent serious health issues, such as that of dietary $\mathrm{Pb}$ intoxication.

Reports of mycotoxin toxicity in Peru are also very few in number, and the available data is suggestive of a possible association. The two studies of consumption of red chili peppers determined that these products were contaminated with AF and OT A, and interestingly, the Peruvian population has a high incidence of gall bladder cancer [76,77]. Similar results were observed in Bolivia and Chile, two high consumers of this pepper variety $[76,119]$. Since mycotoxins are associated with many types of cancers, it is no surprise that consumption of these fungi metabolites is being considered as a risk factor for gall bladder cancer $[120,121]$. The findings encourage the need to control the conditions to avoid the burden of mycotoxin production, and potentially reduce the risk of cancer.

While studies linking cancers and chemical contaminants are limited to mycotoxins in Peru, heavy metals and pesticide residues do pose a carcinogenic risk [122]. Because of the presence of these chemicals at noncompliant levels in Peruvian produce, it is prudent to assume the consumption of these contaminated foods as a risk for the development of cancer. Approximately 19\% of all deaths were attributed to cancers in 2003-2016 in Peru, with stomach cancer being a main contributor to the mortality rate [123]. This statistic is suggestive of a plausible risk of chemically contaminated produce to human health. Moreover, it has been estimated that $70 \%$ of cancer-related deaths will come from low- and middle-income economies by 2030, which would be an increase from the current $56 \%$ [124]. Thus, decreasing the level of chemical contaminants in foods in the upcoming years is a crucial necessity in Peru.

\section{Opportunities to Reduce Chemical Hazards in Produce}

This comprehensive review identified that chemical contaminants in Peruvian produce have frequently been reported to exceed the recommended MRL, becoming a food-safety problem. There is a dire need for closer monitoring for attributing a specific source (e.g., produce or other foods) to chemical intoxications in Peru. The presence of chemical contaminants in sources (e.g., irrigation water) that are directly related to agriculture practices increases the vulnerability of farmed crops. Produce can be chemically contaminated throughout the multiple phases of the farm-to-fork cycle, including farming in the field, during pre- and postharvest activities, storage, packaging, transportation and distribution, and the consumer. Although the laws and regulations regarding chemical contaminants in foods do exist in Peru, the available reports and studies reflect that the current legislation enforcement is not sufficient for appropriately regulating these contaminants in fruits and vegetables.

Crop-management practices can impact the degree of chemical contamination of produce. One key problem in Peruvian agriculture is the reduced awareness about control points to decrease the occurrence of these contaminants in foods. The excessive application of pesticides and the common absence of personal protective equipment during pesticide application are examples of malpractices that can result in chemical contamination affecting produce consumers and field workers, respectively. Pesticide applicators should have a good understanding of how to handle, store, and dispose of these chemicals. Applicators should inspect and calibrate the pesticide-application equipment before spraying crops. Calibration is important to ensure that the pesticide is applied at the right rate over a target area to protect the crops, and reduce nontarget spray damage. The EU established a guideline that can be used as a reference for developing a plan for sustainable use of pesticides [125]. Implementing these measures can help reduce the impact of pesticides on human health and the environment.

Training growers is essential to attain a safer cultivation of foods in Peru. The SENASA agency began to offer trainings on pesticide application in 2015, and has since reached out to more than 10,000 growers in Peru [126]. Other trainings for growers in Peru have 
been focused on practices to reduce mycotoxin load on grains, with the prior approval of SENASA [127]. Such initiatives are appropriate to increase food-safety awareness, and include capacity-building for a better understanding of good agricultural practices, integrated pest management, and mycotoxin-prevention methods. It is important that these trainings are inclusive of growers in rural Peru.

Using untreated water for crop irrigation from rivers that carry industrial effluents may influence pollutant levels in produce. However, farmers in rural areas have limited options for water sources. Thus, it is increasingly important to advocate and push for more compliant wastewater treatment practices. For example, low-cost materials of biological origin (e.g., biochar and agricultural byproducts) have been shown as adsorbents that effectively remove pesticides and heavy metals in water, and could be explored as remediation options [128-130].

It is difficult to assess long-term effects from chemical contaminants in food because chemical contaminants can come from multiple sources throughout a person's lifetime, but consumers have opportunities to reduce the load of chemicals in their produce. Practices such as cooking, peeling, and washing may reduce the levels of pesticide residues in fruits and vegetables [131]. Peeling is the most effective method of reducing pesticide residues, since most pesticides are applied directly to crops. This includes the removal of various organochloride and organophosphate insecticides from potatoes [132]. The boiling method has also been demonstrated to reduce levels of chlorpyrifos residues by at least $50 \%$ in leafy greens and tomatoes [133]. While this is not an absolute solution to the pesticide-residue problem in Peru, implementation of these methods can be a cost-effective solution for consumers that worry about reducing the load of pesticides.

Growers have a vital responsibility to reduce chemical contaminants in produce, and should therefore become aware about the associated food-safety issues. An increased knowledge and understanding of food safety can in turn lead to changes in farm practices in Peru. Food safety in Peru requires a transdisciplinary problem-solving approach, involving the collaboration of the government, nongovernmental organizations, academic institutions, food industries, healthcare systems, and stakeholders. Forming partnerships with universities that emphasize agricultural extension as part of the mission is also an important step to tackle the challenges affecting the agricultural sector in Peru.

The following are recommended initiatives that could help reduce the chemical contamination in produce grown in Peru:

- Strengthen the education pipeline: academic partnerships could help develop and lead training programs that combine research-based knowledge and practical agricultural experience to disseminate information on food-safety practices to the food producers. Training opportunities should be designed and promoted in ways that are accessible to and that engage farmers to adopt and adapt practices that support both agriculture sustainability and food safety.

- Supportive regional agricultural services: investment from the public and private sectors in infrastructure to support small-scale farmers with facilities and equipment, such as refrigerators for storage, and regular calibrations and technical checks of pesticide sprayers for more precise and effective pesticide application and protection of crops.

- Research partnerships: promote research that would develop methods to establish baseline levels for chemical contaminants in soils, irrigation water, and fruits and vegetables. Such baseline data can help locate soil fields, water sources, and crops that are at higher risk of chemical contamination and that require corrective interventions, thus promoting a stronger connection between the food industry and public health.

- Harmonizing food systems and public health: increased coordination and cooperation with the Peruvian healthcare system to implement surveillance systems that will be able to conduct traceback investigations to identify sources of disease outbreaks and stop current foodborne illnesses. Additionally, effective surveillance systems should 
also be able to estimate the long-term burden of foodborne diseases, evaluate priorities, and devise control and preventive measures.

\section{Conclusions}

Exposure to dietary chemical contaminants is well known to have a negative effect on human health. The existing literature highlights that chemical contaminants in Peruvian produce are an issue that deserves continuous monitoring and a thorough health-risk assessment. Otherwise, dietary exposure to these contaminants will increase the risk of chronic diseases, including cancer. Common activities like abundant mining operations and inadequate agricultural practices are challenges for both food safety and public health. A better understanding of the source of chemical contaminants and implementing management practices that can reduce food contamination and human exposure are needed. Addressing these challenges should go hand in hand with improvements in capacity-building and promoting collaboration. Thus, the government, universities, nongovernmental organizations, and the public and private sectors need to come together and invest more efforts to create awareness of the contaminants around them and the importance of management practices that prevent food contamination. Growing safer foods will ultimately benefit both public health and economic prosperity in Peru.

Supplementary Materials: The following are available online at https:/ /www.mdpi.com/article/10 $.3390 /$ foods10071461/s1, Table S1: List of banned pesticides in Peru. Information according to the National Service of Agrarian Health agency. Table S2: List of pesticides commonly used in Peru.

Author Contributions: Conceptualization, methodology, investigation, writing—original draft, writing-review and editing, O.A.G.; conceptualization, resources, writing-review and editing, A.R.-H.; methodology, writing-review and editing, M.V.Á.R., M.d.C.V.O., E.P.V., Y.C., and Y.K.D.-V.; supervision, funding acquisition, writing — review and editing, A.J.D. and H.F.O. All authors have read and agreed to the published version of the manuscript.

Funding: This work received funds to conduct research at the Arequipa Nexus Institute for Food, Energy, Water, and the Environment that were provided by the Universidad Nacional de San Agustin (UNSA), Peru.

Conflicts of Interest: The authors indicate that they have no affiliation or involvement with any organization with a financial interest in or financial competition with the subject matter discussed in this review.

\section{References}

1. Ministerio de Agricultura y Riego (MINAGRI). Boletin Estadistico Mensual "el agro en cifras", Mes: Junio. 2019. Available online: https:/ /www.minagri.gob.pe/portal/download/pdf/herramientas/boletines/agro-cifras/boletin-estadistico-mensualel-agro-en-cifras-junio19-050919.pdf (accessed on 15 March 2021).

2. World Bank. International Bank for Reconstruction and Development International Finance Corporation and Multilateral Investment Guarantee Agency Country Partnership Framework for the Republic of Peru for the Period FY17-FY21. Available online: http:/ / documents.worldbank.org/curated/en/522711493949637279/pdf/Peru-CPF-112299-PE-04102017.pdf (accessed on 15 March 2021).

3. Penny, M.E.; Meza, K.S.; Creed-Kanashiro, H.M.; Marin, R.M.; Donovan, J. Fruits and vegetables are incorporated into home cuisine in different ways that are relevant to promoting increased consumption. Matern. Child Nutr. 2017, 13, e12356. [CrossRef]

4. Schwarz, J.; Mathijs, E. Globalization and the sustainable exploitation of scarce groundwater in coastal Peru. J. Clean. Prod. 2017, 147, 231-241. [CrossRef]

5. Borgoño, N. Reporte de Enfermedades Transmitidas Por Alimentos (ETA) en el Perú. Bol. Epidemiol. Peru 2019, 28, 381-383. Available online: https:/ /www.dge.gob.pe/portal/docs/vigilancia/boletines/2019/15.pdf (accessed on 1 May 2021).

6. Jaffee, S.; Henson, S.; Unnevehr, L.; Grace, D.; Cassou, E. The Safe Food Imperative: Accelerating Progress in Low- and Middle-Income Countries; World Bank Group: Washington, DC, USA; Available online: https://openknowledge.worldbank.org/bitstream/ handle/10986/30568/9781464813450.pdf?sequence=6\&isAllowed=y (accessed on 15 March 2021).

7. World Health Organization (WHO). WHO Estimates of the Global Burden of Foodborne Disease: Foodborne Disease Burden Epidemiology Reference Group 2007-2015. Available online: https://apps.who.int/iris/bitstream/handle/10665/199350/97892 41565165_eng.pdf;jsessionid=36557E6AEC6E64773156483CEFCC5663 (accessed on 15 March 2021). 
8. Kher, S.V.; De Jonge, J.; Wentholt, M.T.A.; Deliza, R.; De Andrade, J.C.; Cnossen, H.J.; Luijckx, N.B.L.; Frewer, L.J. Consumer perceptions of risks of chemical and microbiological contaminants associated with food chains: A cross-national study. Int. J. Consum. Stud. 2013, 37, 73-83. [CrossRef]

9. Nicolopoulou-Stamati, P.; Maipas, S.; Kotampasi, C.; Stamatis, P.; Hens, L. Chemical pesticides and human health: The urgent need for a new concept in agriculture. Front. Public Health 2016, 4, 148. [CrossRef] [PubMed]

10. Omotayo, O.P.; Omotayo, A.O.; Mwanza, M.; Babalola, O.O. Prevalence of Mycotoxins and Their Consequences on Human Health. Toxicol. Res. 2019, 35, 1-7. [CrossRef]

11. United States Environmental Protection Agency (US EPA). Supplementary Guidance for Conducting Health Risk Assessment of Chemical Mixtures. Available online: https:/ / cfpub.epa.gov/ncea/risk/recordisplay.cfm?deid=20533 (accessed on 15 March 2021).

12. Food and Agriculture Organization and World Health Organization (FAO and WHO). Codex Alimentarius CommissionProcedural Manual Twenty-Seventh Edition. Available online: http:/ / www.fao.org/3/ca2329en/CA2329EN.pdf (accessed on 15 March 2021).

13. George, C.M.; Sima, L.; Arias, M.H.; Mihalic, J.; Cabrera, L.Z.; Danz, D.; Checkley, W.; Gilman, R.H. Arsenic exposure in drinking water: An unrecognized health threat in Peru. Bull. World Health Organ. 2014, 92, 565-572. [CrossRef]

14. McCabe-Sellers, B.J.; Beattie, S.E. Food safety: Emerging trends in foodborne illness surveillance and prevention. J. Am. Diet. Assoc. 2004, 104, 1708-1717. [CrossRef] [PubMed]

15. Loza, A. Peru: Food and Agricultural Import Regulations and Standards Report. FAIRS Annual Country Report 2018. United States Department of Agriculture Foreign Agricultural Service. Available online: https://apps.fas.usda.gov/newgainapi/ api $/$ report / downloadreportbyfilename?filename=Food $\% 20$ and $\% 20$ Agricultural $\% 20$ Import $\% 20$ Regulations $\% 20$ and $\% 20$ Standards\%20Report_Lima_Peru_3-22-2019.pdf (accessed on 15 March 2021).

16. Servicio Nacional de Sanidad Agraria (SENASA). Aprueban el Plan Anual de Monitoreo de Residuos Químicos y Otros Contaminantes en Alimentos Agropecuarios Primarios y Piensos, Para el Período Julio a Diciembre del 2019. Directoral Resolution $N^{\circ}$ 0056-2019-MINAGRI-SENASA-DIAIA. Available online: https: / www.senasa.gob.pe/senasa/descargasarchivos / 2019/09/RD-N\%C2\%B0-0056-2019-MINAGRI-SENASA-DIAIA.pdf (accessed on 15 March 2021).

17. Ministerio del Ambiente (MINAM). Aprueban los Estándares Nacionales de Calidad Ambiental Para el Agua. Supreme Decree N004-2017-MINAM. Available online: http:/ / www.minam.gob.pe/wp-content/uploads/2017/06/DS-004-2017-MINAM.pdf (accessed on 15 March 2021).

18. Ministerio del Ambiente (MINAM). Aprueban los Estándares Nacionales de Calidad Ambiental Para Suelo. Supreme Decree N011-2017-MINAM. Available online: http:/ /www.minam.gob.pe/wp-content/uploads/2017/12/DS_011-2017-MINAM.pdf (accessed on 15 March 2021).

19. PROM PERU. Guia de Requisitos de Acceso de Alimentos a los Estados Unidos. Available online: https://www.siicex.gob.pe/ siicex/documentosportal/1025163015radB52B3.pdf (accessed on 15 March 2021).

20. United States Food and Drug Administration (US FDA). FSMA Final Rule on Foreign Supplier Verification Programs (FSVP) for Importers of Food for Humans and Animals. Available online: https:/ / www.fda.gov / food/food-safety-modernization-act-fsma / fsma-final-rule-foreign-supplier-verification-programs-fsvp-importers-food-humans-and-animals (accessed on 15 March 2021).

21. European Commission, Health and Consumers Directorate-General. Final Report of an Audit Carried Out in Peru from 19 to 27 November 2014 in Order to Evaluate Controls of Pesticides in Foods of Plant Origin Intended for Export to the European Union. Available online: http:/ / ec.europa.eu/food/fvo/act_getPDFannx.cfm?ANX_ID=7974 (accessed on 15 March 2021).

22. World Bank. Gaining Momentum in Peruvian Agriculture: Opportunities to Increase Productivity and Enhance Competitiveness. Available online: http:/ / documents1.worldbank.org/curated/pt/107451498513689693/pdf/P162084-06-26-2017-14985136856 23.pdf (accessed on 15 March 2021).

23. World Food Programme. Peru Annual Country Report. 2019. Available online: https://docs.wfp.org/api/documents/WFP-00 00113855/download/ (accessed on 15 March 2021).

24. Chung, B. Control de los contaminantes químicos en el Perú. Rev. Peru. Med. Exp. Salud Pública 2008, 25, 413-418.

25. Ministerio de Agricultura y Riego (MINAGRI). Anuario Estadístico: Medios de Producción Agropecuarios. 2016. Available online: http://siea.minagri.gob.pe/siea/sites/default/files/anuario-medios-produccion-agropecuarios-2016_281217_1.pdf (accessed on 15 March 2021).

26. Cruz-Escalon, A. Situacion Actual del Consumo de Pesticidas en el Peru. Bachelor's Thesis, Facultad de Agronomia, Universidad Nacional Agraria La Molina, Lima, Peru, 2017. Available online: http:/ / repositorio.lamolina.edu.pe/bitstream/handle/UNALM/ 2976/E71-C7-T.pdf?sequence=1\&isAllowed=y (accessed on 15 March 2021).

27. Aquino-Anchirayco, M.S.; Castro-Mere, C.C. Análisis de Residuo de Plaguicida Organofosforado (Methamidophos) en Muestras de Papa de Mercados de Lima Metropolitana. Bachelor's Thesis, Facultad de Farmacia y Quimica, Universidad Nacional Mayor de San Marcos, Lima, Peru, 2008. Available online: http:// cybertesis.unmsm.edu.pe/bitstream/handle/cybertesis/1613/Aquino_ am.pdf (accessed on 15 May 2021).

28. Campos-Chávez, C.; Palacios-Alcántara, A. Determinación por HPLC de Residuos de Insecticida Órganofosforado (Methamidophos) en Tomates Comercializados en Lima-Perú. Bachelor's Thesis, Facultad de Farmacia y Bioquímica, Universidad Nacional Mayor de San Marcos, Lima, Peru, 2010. Available online: https://cybertesis.unmsm.edu.pe/handle/20.500.12672/1611 (accessed on 15 May 2021). 
29. Servicio Nacional de Sanidad Agraria (SENASA). Aprueban Norma Sanitaria Que Establece Los Limites Maximos de Residuos (LMR) de Plaguicidas de Uso Agricola en Alimentos de Consumo Humano. Available online: https://www.senasa.gob. pe/senasa/descargasarchivos /2014/11/RM-1006-2016-MINSA-con-NTS-128-MINSA-2016-DIGESA-LMR-Plaguicidas.pdf (accessed on 15 March 2021).

30. Hjorth, K.; Johansen, K.; Holen, B.; Andersson, A.; Christensen, H.B.; Siivinen, K.; Toome, M. Pesticide residues in fruits and vegetables from South America-A Nordic project. Food Control. 2011, 22, 1701-1706. [CrossRef]

31. Servicio Nacional de Sanidad Agraria (SENASA). Informe del Monitoreo de Contaminantes Quimicos en Alimentos Agropecuarios Primarios, Año 2011; SENASA: Lima, Peru, 2011. Available online: https://www.senasa.gob.pe/senasa/descargasarchivos/2016 /12/Informe-M-2011.pdf (accessed on 15 March 2021).

32. Servicio Nacional de Sanidad Agraria (SENASA). Informe del Monitoreo de Contaminantes Quimicos en Alimentos Agropecuarios Primarios, Año 2012; SENASA: Lima, Peru, 2012. Available online: https://www.senasa.gob.pe/senasa/descargasarchivos/ 2016/12/Informe-del-Monitoreo-de-Residuos-Qu\%C3\%ADmicos-y-otros-Contaminantes-en-Alimentos-AgropecuariosPrimarios-a\%C3\%B1o-2012.pdf (accessed on 15 March 2021).

33. Servicio Nacional de Sanidad Agraria (SENASA). Informe del monitoreo de Contaminantes Químicos en Alimentos Agropecuarios Primarios, Año 2013; SENASA: Lima, Peru, 2013. Available online: https:/ /www.senasa.gob.pe/senasa/descargasarchivos/2016 /12/INFORME_-2013.pdf (accessed on 15 March 2021).

34. Servicio Nacional de Sanidad Agraria (SENASA). Informe del Monitoreo de Contaminantes Químicos en Alimentos Agropecuarios Primarios, Año 2014; SENASA: Lima, Peru, 2014. Available online: https:/ /www.senasa.gob.pe/senasa/descargasarchivos/2016 /08/Informe-de-monitoreo-2014-1.pdf (accessed on 15 March 2021).

35. Servicio Nacional de Sanidad Agraria (SENASA). Informe del Monitoreo de Contaminantes Químicos en Alimentos Agropecuarios Primarios, Año 2015; SENASA: Lima, Peru, 2015. Available online: https:/ /www.senasa.gob.pe/senasa/descargasarchivos/2016 /08/Informe-de-monitoreo.pdf (accessed on 15 March 2021).

36. Servicio Nacional de Sanidad Agraria (SENASA). Informe del Monitoreo de Contaminantes Químicos en Alimentos Agropecuarios Primarios, Año 2016; SENASA: Lima, Peru, 2016. Available online: https:/ /www.senasa.gob.pe/senasa/descargasarchivos/2016 /08/Informe-de-monitoreo-2016.pdf (accessed on 15 March 2021).

37. Servicio Nacional de Sanidad Agraria (SENASA). Informe del Monitoreo de Contaminantes Quimicos en Alimentos Agropecuarios Primarios, Año 2017; SENASA: Lima, Peru, 2017. Available online: https:/ /www.senasa.gob.pe/senasa/descargasarchivos/2018 /12/INFORME-FINAL-DEL-PLAN-DE-MONITOREO-2017-1.pdf (accessed on 15 March 2021).

38. Servicio Nacional de Sanidad Agraria (SENASA). Informe del Monitoreo de Contaminantes Quimicos en Alimentos Agropecuarios Primarios, Año 2018; SENASA: Lima, Peru, 2018. Available online: https:/ /www.senasa.gob.pe/senasa/descargasarchivos/2020 /06/INFORME-FINAL-DEL-PLAN-DE-MONITOREO-2018-revisi\%C3\%B3n-31.03.docx (accessed on 15 March 2021).

39. Servicio Nacional de Sanidad Agraria (SENASA). Informe del Monitoreo de Contaminantes Químicos en Alimentos Agropecuarios Primarios, Año 2019; SENASA: Lima, Peru, 2019. Available online: https://cdn.www.gob.pe/uploads/document/file/1516765/ Informe\%20del\%20plan\%20anual\%20de\%20monitoreo\%20de\%20contaminantes\%202019.pdf (accessed on 15 March 2021).

40. Delgado-Zegarra, J.; Alvarez-Risco, A.; Yáñez, J.A. Indiscriminate use of pesticides and lack of sanitary control in the domestic market in Peru. Pan Am. J. Public Health 2018, 42, e3. [CrossRef]

41. United States Food and Drug Administration (US FDA). Import Alerts for a Country/Area: Peru. Available online: https: //www.accessdata.fda.gov/cms_ia/country_PE.html (accessed on 15 March 2021).

42. Zhang, Z.Y.; Liu, X.J.; Yu, X.Y.; Zhang, C.Z.; Hong, X.Y. Pesticide residues in the spring cabbage (Brassica oleracea L. var. capitata) grown in open field. Food Control. 2007, 18, 723-730. [CrossRef]

43. Elgueta, S.; Moyano, S.; Sepúlveda, P.; Quiroz, C.; Correa, A. Pesticide residues in leafy vegetables and human health risk assessment in North Central agricultural areas of Chile. Food Addit. Contam. Part. B Surveill. 2017, 10, 105-112. [CrossRef]

44. Tchounwou, P.B.; Yedjou, C.G.; Patlolla, A.K.; Sutton, D.J. Heavy metal toxicity and the environment. In Molecular, Clinical and Environmental Toxicology; Luch, A., Ed.; Springer: Basel, Switzerland, 2012; Volume 101, pp. 133-164. [CrossRef]

45. Morgan, J.B.; Connolly, E.L. Plant-soil interactions: Nutrient uptake. Nat. Educ. Knowl. 2013, 4, 2.

46. Kabata-Pendias, A.; Mukherjee, A.B. Trace Elements from Soil to Human, 1st ed.; Springer: New York, NY, USA, 2007 ; pp. 3-85.

47. De la Flor, P.; Mining and Economic Development in Peru. Article in Revista Harvard Review of Latin America. Available online: http: / / revista.drclas.harvard.edu/files/revista / files/37165_pandr_revista_proof.pdf?m=1410442834 (accessed on 15 March 2021).

48. Bebbington, A.; Williams, M. Water and mining conflicts in Peru. Mt. Res. Dev. 2008, 28, 190-195. [CrossRef]

49. Tasrina, R.C.; Rowshon, A.; Mustafizur, A.M.R.; Rafiqul, I.; Ali, M.P. Heavy metals contamination in vegetables and its growing soil. J. Environ. Anal. Chem. 2015, 2, 142. [CrossRef]

50. van Geen, A.; Bravo, C.; Gil, V.; Sherpa, S.; Jack, D. Lead exposure from soil in Peruvian mining towns: A national assessment supported by two contrasting examples. Bull. World Health Organ. 2012, 90, 878-886. [CrossRef] [PubMed]

51. Barenys, M.; Boix, N.; Farran-Codina, A.; Palma-Linares, I.; Montserrat, R.; Curto, A.; Gomez-Catalan, J.; Ortiz, P.; Deza, N.; Llobet, J.M. Heavy metal and metalloids intake risk assessment in the diet of a rural population living near a gold mine in the Peruvian Andes (Cajamarca). Food Chem. Toxicol. 2014, 71, 254-263. [CrossRef]

52. Jassir, M.; Shaker, A.; Khaliq, M.A. Deposition of heavy metals on green leafy vegetables sold on roadsides of Riyadh City, Saudi Arabia. Bull. Environ. Contam. Toxicol. 2005, 75, 1020-1027. [CrossRef] [PubMed] 
53. Zhang, F.; Yan, X.; Zeng, C.; Zhang, M.; Shrestha, S.; Devkota, L.P.; Yao, T. Influence of traffic activity on heavy metal concentrations of roadside farmland soil in mountainous areas. Int. J. Environ. Res. Public Health 2012, 9, 1715-1731. [CrossRef]

54. Calderon, E.L.; Calderon, P.D. Concentración de Metales Pesados en Hortalizas que se Comercializan en el Consumo Modelo de Piura. Revista en Internet, Departamento Académico de Ingeniería Química, Universidad Nacional de Piura, Perú. 2002. Available online: http:/ / www.unp.edu.pe/institutos/iipd/trabajosinvestigacion/NUEVOS\%20TRABAJOS\%20A\%20PUBLICAR/ MINAS/Trabajo\%20de\%20Investigacion-Esther\%20calderon2.docx (accessed on 15 May 2021).

55. Madueño, F.; García, M. Determinación de metales pesados (Plomo y Cadmio) en lechuga (Lactuca sativa) de mercados de Lima metropolitana. Cienc. Investig. 2018, 21, 19-23. [CrossRef]

56. Calderon, E.L.; Concha, R. Evaluación de las Concentraciones de Metales Pesados Para Determinar la Calidad de frutas de Consumo Masivo en la Ciudad de Piura. Online Article, Departamento Académico de Ingeniería Química, Universidad Nacional de Piura, Peru. 2012. Available online: http:/ / www.unp.edu.pe/institutos/iipd/trabajosinvestigacion/facultadminasquimicaesthercalderon.pdf (accessed on 15 May 2021).

57. Custodio, M.; Peñaloza, R.; Orellana, E.; Aguilar-Cáceres, M.A.; Maldonado-Oré, E.M. Heavy metals and arsenic in soil and cereal grains and potential human risk in the central region of Peru. J. Ecol. Eng. 2021, 22, 206-220. [CrossRef]

58. Zug, K.L.M.; Huamaní-Yupanqui, H.A.; Meyberg, F.; Cierjacks, J.S.; Cierjacks, A. Cadmium accumulation in Peruvian cacao (Theobroma cacao L.) and opportunities for mitigation. Water Air Soil Pollut. 2019, 230, 72. [CrossRef]

59. Arévalo-Gardini, E.; Arévalo-Hernández, C.O.; Baligar, V.C.; He, Z.L. Heavy metal accumulation in leaves and beans of cacao (Theobroma cacao L.) in major cacao growing regions in Peru. Sci. Total Environ. 2017, 605-606, 792-800. [CrossRef] [PubMed]

60. Rosales-Huamani, J.A.; Breña-Ore, J.L.; Sespedes-Varkarsel, S.; Huamanchumo de la Cuba, L.; Centeno-Rojas, L.; Otiniano-Zavala, A.; Andrade-Choque, J.; Valverde-Espinoza, S.; Castillo-Sequera, J.L. Study to determine levels of cadmium in cocoa crops applied to inland areas of Peru: "The case of the Campo Verde-Honoria Tournavista corridor". Agronomy 2020, 10, 1576. [CrossRef]

61. Soto-Benavente, M.; Rodriguez-Achata, L.; Olivera, M.; Arostegui-Sanchez, V.; Colina-Nano, C.; Garate-Quispe, J. Riesgos para la salud por metales pesados en productos agrícolas cultivados en áreas abandonadas por la minería aurífera en la Amazonía peruana. Sci. Agropecu. 2020, 11, 49-59. [CrossRef]

62. De la O-Valenzuela, Z.O.; Quispe-Aguirre, J.; Cardenas-Orihuela, R.A. Determinación Cuantitativa de Plomo y Cadmio en Diez Tipos de Yuca (Manihot Esculenta) Comercializadas en el Mercado del Distrito de San Martin de Pangoa, de la Ciudad de Satipo, Departamento de Junin, de Enero a Marzo de 2017. Bachelor's Thesis, Facultad de Farmacia y Bioquimica, Universidad Wiener, Arequipa, Peru, 2017. Available online: http:/ / repositorio.uwiener.edu.pe/handle/123456789/1187 (accessed on 15 March 2021).

63. Quispe-Cruz, N.M.; Paredez de Gómez, T.B. Evaluacion del Riesgo de Toxicidad a Traves de Contaminantes en Cultivos Agricolas de Tallo Corto en la Cuenca Media Quilca-Vitor-Chili, Los Tunales Tiabaya. Bachelor's Thesis, Facultad Ingenieria de Procesos, Universidad Nacional de San Agustin de Arequipa, Peru. Available online: http:/ / repositorio.unsa.edu.pe/handle/UNSA/10804 (accessed on 15 March 2021).

64. Román-Ochoa, Y.; Delgado, G.; Tejada, T.; Yucra, H.; Durand, A.; Hamaker, B. Heavy metal contamination and health risk assessment in grains and grain-based processed food in Arequipa region of Peru. Chemosphere 2021, 274, 129792. [CrossRef]

65. Juan de Dios-Miranda, M.K. Niveles de Arsénico y Cadmio en Muestras de Cebolla (Allium cepa) Expendidas en la Ciudad de Lima. Bachelor's Thesis, Facultad de Farmacia y Bioquimica, Universidad Nacional Mayor de San Marcos, Lima, Peru, 2018. Available online: https:/ / cybertesis.unmsm.edu.pe/handle/20.500.12672/8873 (accessed on 15 March 2021).

66. López, D.L.; García, O.M.; Madueño, V.F.; Bautista, C.N.; Marín, V.G.; Olórtegui, C.D. Metales pesados en tres variedades de Solanum tuberosum L. (papa) expendidos en el mercado mayorista de Santa Anita (Lima-Peru). Cienc. Investig. 2020, 23, 25-30. [CrossRef]

67. Luna-Arenas, R.N.; Rodríguez-Lozada, V.A.; Lizano-Gutiérrez, J.V. Determinación de las Concentraciones de Cadmio y Plomo en Papa (Solanum Tuberosum) Cosechada en las Cuencas de los Ríos Mashcón y Chonta-Cajamarca. Bachelor's Thesis, Facultad de Farmacia y Bioquimica, Universidad Nacional Mayor de San Marcos, Lima, Peru, 2016. Available online: https: / / cybertesis. unmsm.edu.pe/handle/20.500.12672/4678 (accessed on 15 March 2021).

68. Orellana, E.; Bastos, M.C.; Cuadrado, W.; Zárate, R.; Sarapura, V.; Yallico, L.; Tabra, F.; Bao, D. Heavy metals in native potato and health risk assessment in highland Andean zones of Junin, Peru. J. Environ. Prot. 2020, 11, 921-937. [CrossRef]

69. Mondal, D.; Periche, R.; Tineo, B.; Bermejo, L.A.; Rahman, M.M.; Siddique, A.B.; Rahman, M.A.; Solis, J.L.; Cruz, G. Arsenic in Peruvian rice cultivated in the major rice growing region of Tumbes river basin. Chemosphere 2020, 241, 125070. [CrossRef]

70. Aguilar, M.; Mondaca, P.; Ginocchio, R.; Vidal, K.; Sauvé, S.; Neaman, A. Comparison of exposure to trace elements through vegetable consumption between a mining area and an agricultural area in central Chile. Environ. Sci. Pollut. Res. Int. 2018, 25, 19114-19121. [CrossRef]

71. Musilova, J.; Bystricka, J.; Vollmannova, A.; Janotova, B.; Orsak, M.; Harangozo, L.; Hegedusova, A. Safety of potato consumption in slovak region contaminated by heavy metals due to previous mining activity. J. Food Qual. 2017, 1-11. [CrossRef]

72. Peng, Y.; Yang, R.; Jin, T.; Chen, J.; Zhang, J. Risk assessment for potentially toxic metal(loid)s in potatoes in the indigenous zinc smelting area of northwestern Guizhou Province, China. Food Chem. Toxicol. 2018, 120, 328-339. [CrossRef]

73. Servicio Nacional de Sanidad Agraria (SENASA). Plan Anual de Monitoreo de Residous Quimicos y Otros Contaminantes en Alimentos Aagropecuarios Primarios y Piensos Para el año. 2020. Available online: https:/ /www.senasa.gob.pe/senasa/ descargasarchivos/2020/08/PLAN-ANUAL-DE-MONITOREO-2020-27.07.pdf (accessed on 15 March 2021). 
74. Alshannaq, A.; Yu, J.H. Occurrence, toxicity, and analysis of major mycotoxins in food. Int. J. Environ. Res. Public Health 2017, 14, 632. [CrossRef] [PubMed]

75. Almela, L.; Rabe, V.; Sánchez, B.; Torrella, F.; López-Pérez, J.P.; Gabaldón, J.A.; Guardiola, L. Ochratoxin A in red paprika: Relationship with the origin of the raw material. Food Microbiol. 2007, 24, 319-327. [CrossRef] [PubMed]

76. Ikoma, T.; Tsuchiya, Y.; Asai, T.; Okano, K.; Ito, N.; Endoh, K.; Yamamoto, M.; Nakamura, K. Ochratoxin A contamination of red chili peppers from Chile, Bolivia and Peru, Countries with a high incidence of gallbladder cancer. Asian Pac. J. Cancer Prev. 2015, 16, 5987-5991. [CrossRef] [PubMed]

77. Asai, T.; Tsuchiya, Y.; Okano, K.; Piscoya, A.; Nishi, C.Y.; Ikoma, T.; Oyama, T.; Ikegami, K.; Yamamoto, M. Aflatoxin contamination of red chili pepper from Bolivia and Peru, countries with high gallbladder cancer incidence rates. Asian Pac. J. Cancer Prev. 2012, 13, 5167-5170. [CrossRef] [PubMed]

78. Coloma, Z.N.; Oliveira, M.S.; Dilkin, P.; Mallmann, A.O.; Almeida, C.A.A.; Mallmann, C.A. Mycotoxin occurrence in Peruvian purple maize. World Mycotoxin J. 2019, 12, 307-315. [CrossRef]

79. Oliveira, M.S.; Rocha, A.; Sulyok, M.; Krska, R.; Mallmann, C.A. Natural mycotoxin contamination of maize (Zea mays L.) in the south region of Brazil. Food Control. 2017, 73, 127-132. [CrossRef]

80. Ashiq, S. Natural occurrence of mycotoxins in food and feed: Pakistan perspective. Compr. Rev. Food Sci. Food Saf. 2015, 14, 159-175. [CrossRef]

81. Soriano, M.; Bejar, V.; Bonilla, P. Frecuencia de hongos anemófilos productores de micotoxinas en algunos mercados de Lima. Detección de patulinas en manzanas en descomposición. Cienc. Investig. 2002, 5, 36-45. [CrossRef]

82. Food and Agriculture Organization (FAO). Code of Practice for the Prevention and Reduction of Patulin Contamination in Apple Juice and Apple Juice Ingredients in Other Beverages; Food and Agriculture Organization: Rome, Italy, 2003; Volume 50, pp. 1-8. Available online: http:/ / www.fao.org/input/download/standards /405/CXP_050e.pdf (accessed on 15 March 2021).

83. García-Díaz, M.; Gil-Serna, J.; Vázquez, C.; Botia, M.N.; Patiño, B. A comprehensive study on the occurrence of mycotoxins and their producing fungi during the maize production cycle in Spain. Microorganisms 2020, 8, 141. [CrossRef] [PubMed]

84. Granados-Chinchilla, F.; Molina, A.; Chavarría, G.; Alfaro-Cascante, M.; Bogantes-Ledezma, D.; Murillo-Williams, A. Aflatoxins occurrence through the foodchain in Costa Rica: Applying the one health approach to mycotoxin surveillance. Food Control. 2017, 82, 217-226. [CrossRef]

85. Ministerio de Agricultura y Riego (MINAGRI). Contenidos Minimos del Programa Presupuestal: Aprovechamientos de Los Recursos Hidricos Para Uso Agrario. Available online: http:/ /minagri.gob.pe/portal/download/programas-presupuestales/ inf-programa/anexo2-pp42-2017.pdf (accessed on 15 March 2021).

86. Ministerio de Agricultura y Riego (MINAGRI). Contaminacion del Agua. Available online: https://www.minagri.gob.pe/portal/ 54-sector-agrario/cuencas-e-hidrografia/374-problematica (accessed on 15 March 2021).

87. Palm, B.; Kylic, H.; Chappa-Santa Maria, C. Pesticide Use in Rice Cultivation in Tarapoto, Peru. Usage Patterns and Pesticide Residues in Water Sources. Master's Thesis, Department of Environmental Assessment, Swedish University of Agricultural Sciences, Uppsala, Sweden, 2007. Available online: https://stud.epsilon.slu.se/12968/1/palm_b_171117.pdf (accessed on 15 March 2021).

88. Bergmann, A.J.; North, P.E.; Vasquez, L.; Bello, H.; Gastañaga Ruiz, M.D.C.; Anderson, K.A. Multi-class chemical exposure in rural Peru using silicone wristbands. J. Expo. Sci. Environ. Epidemiol. 2017, 27, 560-568. [CrossRef]

89. Pacherres-Pinto, M.L.; Ramos-Gorbeña, J.C. Determinación de la Calidad de Agua de las Cuencas de Los Ríos Chillón, Rímac y Lurín Mediante Indicadores Químicos y Biológicos. Bachelor's Thesis, Facultad de Ciencias Biologicas, Universidad Ricardo Palma, Santiago de Surco, Peru, 2019. Available online: http://repositorio.urp.edu.pe/handle/URP/2838 (accessed on 15 March 2021).

90. Custodio, M.; Álvarez, D.; Cuadrado, W.; Montalvo, R.; Ochoa, S. Potentially toxic metals and metalloids in surface water intended for human consumption and other uses in the Mantaro River watershed, Peru. Soil Water Res. 2020, 15, 237-245. [CrossRef]

91. Quispe-Zuñiga, M.R.; Santos, F.; Callo-Concha, D.; Greve, K. Impact of heavy metals on community farming activities in the Central Peruvian Andes. Minerals 2019, 9, 647. [CrossRef]

92. Huaranga-Moreno, F.; Méndez-García, E.; Quilcat-León, V.; Huaranga-Arévalo, F. Contaminacion por Metales Pesados en la Cuenca del rio Moche, 1980-2010, La Libertad-Peru. Sci. Agropecu. 2012, 3, 235-247. Available online: https:/ / revistas.unitru.edu. pe/index.php/scientiaagrop/article/download/86/96 (accessed on 15 March 2021).

93. Autoridad Nacional del Agua (ANA). Plan Maestro del Proyecto de Restauración del río Rímac: Informe Final. Available online: https:/ / hdl.handle.net/20.500.12543/637 (accessed on 15 May 2021).

94. Flores-Lozano, H.H.; Lara-Ascorbe, D. Evaluación de la Concentración de Metales Pesados en las Aguas del río Grande y Su Relación con la Actividad Minera. Master's Thesis, Escuela de Posgrado, Universidad Nacional de Cajamarca, Cajamarca, Peru, 2016. Available online: http:/ / repositorio.unc.edu.pe/handle/UNC/1299 (accessed on 15 March 2021).

95. Sotero-Solis, V.; Alva-Astudillo, M. Contenido de metales pesados en agua y sedimento en el bajo Nanay. Cienc. Amaz. 2013, 3, 24-32. [CrossRef]

96. Salas-Urviola, F.B. Determinación de Metales Pesados en las Aguas del río Ananea Debido a la Actividad Minera Aurífera, Puno-Perú. Rev. Investig. Esc. Posgrado-Univ. Nac. Altiplano Puno-Perú 2014, 5, 47-53. Available online: http://revistas.unap.edu. pe/epg/index.php/investigaciones/article/view/14/11 (accessed on 15 March 2021). 
97. Garcia-Flores de Nieto, B.V.; Diaz-Rodriguez, J. Contaminación del Agua por Metales Pesados As, B, Cu, Pb, Cd y CN- en las Cuencas de los Ríos Tambo, Quilca, Camaná y Ocoña de la Región Arequipa. Ph.D. Thesis, Escuela de Posgrado, Universidad Nacional de San Agustin de Arequipa, Arequipa, Peru, 2019. Available online: http://repositorio.unsa.edu.pe/handle/UNSA/ 10764 (accessed on 15 March 2021).

98. Peña-Quispe, G.; Yabarrena-Uscamayta, L.A. Estudio del Efecto de Contaminación de los Productos Agrícolas Irrigados con Aguas de la Subcuenca del rio Huatanay, Cusco-Perú. Bachelor's Thesis, Facultad de Ciencias Agrarias, 2019. Available online: http:/ / repositorio.unsaac.edu.pe/handle/UNSAAC/4259 (accessed on 15 March 2021).

99. Chung-Tong, B. La Minería Aurífera en el Perú y la Contaminación del Ambiente. Rev. Acad. Peru Salud 2011, 18. Available online: https://sisbib.unmsm.edu.pe/BVRevistas/rev_academia/2011_n2/pdf/a14v18n2.pdf (accessed on 15 March 2021).

100. Prüss-Ustün, A.; Vickers, C.; Haefliger, P.; Bertollini, R. Knowns and unknowns on burden of disease due to chemicals: A systematic review. Environ. Health 2011, 10, 9. [CrossRef]

101. Järup, L. Hazards of heavy metal contamination. Br. Med. Bull. 2003, 68, 167-182. [CrossRef] [PubMed]

102. Kim, K.H.; Kabir, E.; Jahan, S.A. Exposure to pesticides and the associated human health effects. Sci. Total Environ. 2017, 575, 525-535. [CrossRef] [PubMed]

103. Consorcio Agroecologico Peruano. Propuesta de Lista de Plaguicidas a ser Prohibidos o Restringidos. Available online: http:/ / consorcioagroecologico.pe/wp-content/uploads/2020/08/LISTA-DE-PLAGUICIDAS-impreso-2019.pdf (accessed on 3 May 2021).

104. Osorio, L.G.; Murray, D.; Rosenthal, E. Corporate impunity in Taucamarca: 19 years on, still no justice. Bus. Hum. Rights J. 2019, 4, 329-336. [CrossRef]

105. El Comercio. Ayacucho: Revelan en Qué Alimentos se Halló Plaguicida Que Causó Intoxicación Masiva. Available online: https:/ / elcomercio.pe/peru/ayacucho/ayacucho-revelan-producto-hallo-plaguicida-causo-intoxicacion-masiva-noticia559012-noticia/ (accessed on 2 May 2021).

106. Ministerio de Salud (MINSA). Sala de Situación de Salud: Vigilancia Epidemiológica del Riesgo de Exposición e Intoxicación por Plaguicidas. Available online: https://www.dge.gob.pe/portal/docs/vigilancia/sala/2019/SE29/plaguicidas.pdf (accessed on 15 March 2021).

107. Cataño, H.C.; Carranza, E.; Huamaní, C.; Hernández, A.F. Plasma cholinesterase levels and health symptoms in Peruvian farm workers exposed to organophosphate pesticides. Arch. Environ. Contam. Toxicol. 2008, 55, 153-159. [CrossRef] [PubMed]

108. Montoro, Y.; Moreno, R.; Gomero, L.; Reyes, M. Características de uso de plaguicidas quimicos y riesgos para la salud en agricultores de la Sierra Central del Perú. Rev. Peru. Med. Exp. Salud Publica 2009, 26, 466-472.

109. Yucra, S.; Steenland, K.; Chung, A.; Choque, F.; Gonzales, G.F. Dialkyl phosphate metabolites of organophosphorus in applicators of agricultural pesticides in Majes-Arequipa (Peru). J. Occup. Med. Toxicol. 2006, 1, 27. [CrossRef] [PubMed]

110. Ministerio de Salud (MINSA). Vigilancia Epidemiologica Exposicion a Metales Pesados. Available online: http:/ /www.dge.gob. pe/portal/docs/tools/teleconferencia/2019/SE082019/04.pdf (accessed on 15 March 2021).

111. Castro-Bedriñana, J.; Chirinos-Peinado, D.; Ríos-Ríos, E. Niveles de plomo en gestantes y consumo en la ciudad de la Oroya, Perú. Rev. Peru. Med. Exp. Salud Publica 2013, 30, 393-398. [CrossRef]

112. Borja-Aburto, V.; Hertz-Picciotto, I.; Lopez, M.; Farias, P.; Rios, C.; Blanco, J. Blood lead levels measured prospectively and risk of spontaneous abortion. Am. J. Epidemiol. 1999, 150, 590-597. [CrossRef]

113. Hertz-Picciotto, I. The evidence that lead increases the risk for spontaneous abortion. Am. J. Ind. Med. 2000, 38, 300-309. [CrossRef]

114. Cederstav, A.; Barandiarán, A. La Oroya Cannot Wait. Sociedad Peruana de Derecho Ambiental. Available online: https: / / aida-americas.org/sites/default/files/publication/La_Oroya_Cannot_Wait_1_0.pdf (accessed on 15 March 2021).

115. UNICEF. The Toxic Truth: Children's Exposure to Lead Pollution Undermines a Generation of Future Potential. Available online: https: / / www.unicef.org/media/73246/ file/The-toxic-truth-children\%E2\%80\%99s-exposure-to-lead-pollution-2020.pdf (accessed on 30 May 2021).

116. Vega-Dienstmaier, J.M.; Salinas-Piélago, J.E.; Gutiérrez-Campos, M.D.R.; Mandamiento-Ayquipa, R.D.; Yara-Hokama, M.D.C.; Ponce-Canchihuamán, J.; Castro-Morales, J. Lead levels and cognitive abilities in Peruvian children. Rev. Bras Psiquiatr. 2006, 28, 33-39. [CrossRef]

117. Tchernitchin, A.N.; Lapin, N.; Molina, L.; Molina, G.; Tchernitchin, N.A.; Acevedo, C.; Alonso, P. Human exposure to lead in Chile. In Reviews of Environmental Contamination and Toxicology; George, W.W., Herbert, N.N., Daniel, R.D., Eds.; Springer: New York, NY, USA, 2006; pp. 93-139. [CrossRef]

118. Wani, A.L.; Ara, A.; Usmani, J.A. Lead toxicity: A review. Interdiscip. Toxicol. 2015, 8, 55-64. [CrossRef]

119. Tsuchiya, Y.; Terao, M.; Okano, K.; Nakamura, K.; Oyama, M.; Ikegami, K.; Yamamoto, M. Mutagenicity and mutagens of the red chili pepper as gallbladder cancer risk factor in Chilean women. Asian Pac. J. Cancer Prev. 2011, 12, 471-476.

120. Costa, J.; Rodríguez, R.; Garcia-Cela, E.; Medina, A.; Magan, N.; Lima, N.; Battilani, P.; Santos, C. Overview of fungi and mycotoxin contamination in Capsicum pepper and in its derivatives. Toxins 2019, 11, 27. [CrossRef] [PubMed]

121. Koshiol, J.; Gao, Y.T.; Dean, M.; Egner, P.; Nepal, C.; Jones, K.; Wang, B.; Rashid, A.; Luo, W.; Van Dyke, A.L.; et al. Association of Aflatoxin and Gallbladder Cancer. Gastroenterology 2017, 153, 488-494.e1. [CrossRef]

122. Eskola, M.; Elliott, C.T.; Hajšlová, J.; Steiner, D.; Krska, R. Towards a dietary-exposome assessment of chemicals in food: An update on the chronic health risks for the European consumer. Crit. Rev. Food Sci. Nutr. 2020, 60, 1890-1911. [CrossRef] [PubMed] 
123. Zafra-Tanaka, J.H.; Tenorio-Mucha, J.; Villarreal-Zegarra, D.; Carrillo-Larco, R.; Bernabe-Ortiz, A. Cancer-related mortality in Peru: Trends from 2003 to 2016. PLoS ONE 2020, 15, e0228867. [CrossRef]

124. Anyanwu, B.O.; Ezejiofor, A.N.; Igweze, Z.N.; Orisakwe, O.E. Heavy metal mixture exposure and effects in developing nations: An update. Toxics 2018, 6, 65. [CrossRef] [PubMed]

125. OJEU. Directive 2009/128/EC of the European Parliament and of the Council of 21 October 2009 Establishing a Framework for Community Action to Achieve Thesustainable Use of Pesticides (Text with EEA Relevance). Available online: https: / / eur-lex.europa.eu/legal-content/EN/TXT/PDF/?uri=CELEX:02009L0128-20190726\&from=EN (accessed on 18 June 2021).

126. Servicio Nacional de Sanidad Agraria (SENASA). Miles de Agricultores ya Aplican Control Biológico Para Manejo de Plagas. Available online: https:/ / www.senasa.gob.pe/senasacontigo/miles-de-agricultores-ya-aplican-control-biologico-para-manejode-plagas / (accessed on 15 March 2021).

127. International Maize and Wheat Improvement Center. Training on Mycotoxins Supports Peruvian Maize Exports. Available online: https:/ / www.cimmyt.org/news/training-on-mycotoxins-supports-peruvian-maize-exports/ (accessed on 15 March 2021).

128. Garcia-Chevesich, P.; García, V.; Martínez, G.; Zea, J.; Ticona, J.; Alejo, F.; Vanneste, J.; Acker, S.; Vanzin, G.; Malone, A.; et al. Inexpensive organic materials and their applications towards heavy metal attenuation in waters from southern Peru. Water 2020, 12, 2948. [CrossRef]

129. Memon, G.Z.; Bhanger, M.I.; Akhtar, M.; Talpur, F.N.; Memon, J.R. Adsorption of methyl parathion pesticide from water using watermelon peels as a low cost adsorbent. Chem. Eng. Sci. 2008, 138, 616-621. [CrossRef]

130. Zhao, J.; Shen, X.; Domene, X.; Alcañiz, J.; Liao, X.; Palet, C. Comparison of biochars derived from different types of feedstock and their potential for heavy metal removal in multiple-metal solutions. Sci. Rep. 2019, 9, 9869. [CrossRef]

131. Syed, J.H.; Alamdar, A.; Mohammad, A.; Ahad, K.; Shabir, Z.; Ahmed, H.; Ali, S.M.; Sani, S.G.; Bokhari, H.; Gallagher, K.D.; et al. Pesticide residues in fruits and vegetables from Pakistan: A review of the occurrence and associated human health risks. Environ. Sci. Pollut. Res. 2014, 21, 13367-13393. [CrossRef]

132. Chung, S.W. How effective are common household preparations on removing pesticide residues from fruit and vegetables? A review. J. Sci. Food Agric. 2018, 98, 2857-2870. [CrossRef] [PubMed]

133. Ling, Y.; Wang, H.; Yong, W.; Zhang, F.; Sun, L.; Yang, M.L.; Wu, Y.N.; Chu, X.G. The effects of washing and cooking on chlorpyrifos and its toxic metabolites in vegetables. Food Control. 2011, 22, 54-58. [CrossRef] 